\section{LAS INDUSTRIAS ARTÍSTICAS EN LA ESPAÑA DEL SIGLO XX. FUNDACIÓN GENERALÍSIMO FRANCO, FUNDACIÓN DE GREMIOS, NUEVA FUNDACIÓN DE GREMIOS: APORTACIONES A LA HISTORIA DE UNA EMPRESA ARTÍSTICA ESPAÑOLA \\ THE ARTISTIC INDUSTRIES IN SPAIN IN THE 20TH CENTURY. GENERALISSIMO FRANCO FOUNDATION, GUILDS FOUNDATION, NEW GUILDS FOUNDATION: CONTRIBUTIONS TO THE HISTORY OF A SPANISH ARTISTIC COMPANY} Investigadora Independiente

\title{
Resumen
}

Las artes decorativas experimentaron en España un importante desarrollo en los años centrales del pasado siglo. A este resurgimiento colaboró una empresa artística española, nacida en 1941 como fundación privada: la Fundación Generalísimo Franco -Industrias Artísticas Agrupadas (Fundación de Gremios desde 1984 y Nueva Fundación de Gremios a parir de 1989), que puso en marcha una gran variedad de talleres, la mayoría de los cuales estuvieron activos durante los cincuenta y cuatro años de su existencia. Los cambios en su naturaleza jurídica tuvieron incidencia directa en la organización interna y en la producción, pero no afectaron a una de sus señas de identidad más desconocidas, el deseo de incorporar la modernidad en todos sus diseños.

Palabras Clave: Artes decorativas. Diseño de interiores. Textil: Tapices, alfombras, seda, bordados y reposteros. Historia del mueble. Porcelana española. Franquismo.

\section{Introducción}

"Aunque la actividad de esta institución se mantuvo hasta 1995 con diferentes denominaciones, carácter jurídico y estructura empresarial, se conoce hasta la fecha muy poco de su funcionamiento, clientela, obras y modelos (...), su historia está aún por escribir ${ }^{1 "}$.

Con estas palabras abre Ana María Fernández García su interesante estudio sobre la producción del taller de muebles de la Fundación Generalísimo Franco-Industrias Artísticas Agrupadas (Fundación de Gremios desde 1984, y Nueva Fundación de Gremios a partir de 1989), y son estas mismas palabras las que nos inducen a escribir este artículo que, esperamos, permi-

*E-mail: viantapices@telefonica.net 
tirá esclarecer algunos aspectos de la historia y producción de la Fundación ${ }^{2}$. Los objetivos concretos que se propone el presente escrito son los siguientes:

- Hacer algunas observaciones o ampliaciones a ciertos datos expuestos en el artículo de la doctora Fernández.

- Contribuir al conocimiento de la gestión y organización interna de la Fundación, aportando documentos inéditos: los cuatro últimos Organigramas y el listado completo de los empleados del área textil durante la tercera etapa de su existencia.

Para comenzar, es preciso hacer una primera acotación: la historia de la Fundación sí está escrita, y fue publicada en el año 2013 como parte de una obra general destinada al estudio de la tapicería española del siglo $\mathrm{XX}^{3}$. Por las páginas de este libro desfilaron manufacturas históricas como la Real Fábrica de Tapices pero también todas las de nueva creación, entre las que destacaba la Fundación. El hecho de que su historia esté incluida en un libro dedicado al arte del tapiz ha sido la causa probable de que pasara desapercibida para los investigadores de otras especialidades.

El estudio de la documentación relacionada con la mayoría de los centros de producción revistió las dificultades habituales de cualquier investigación histórica, pero en el caso de la Fundación se transformó en un trabajo cargado de obstáculos. La razón estribaba en la dispersión de su archivo documental, que se produjo tras el cierre de la empresa en 1995. Varios años de trabajo y la consulta en los archivos de doce instituciones diferentes y varios privados, fueron necesarios para reconstruir la crónica de su existencia desde los meses anteriores a su efectiva creación hasta siete años después de su extinción, tiempo que se tardó en completar el proceso liquidador. Así mismo se publicaron en un Apéndice del citado libro los Estatutos de 1941 y las sucesivas modificaciones ${ }^{4}$.

Señalemos además que, al describir los pormenores de las distintas fases de su historia, se enunció la composición de sus órganos rectores con la expresión de los nombres de las personas que asumieron los diferentes cargos en el Patronato, el Consejo de Administración y el Consejo Asesor Artístico. Igualmente aparecen citados algunos de los integrantes de los talleres y de otros departamentos.

La bibliografía sobre la Fundación hasta esa fecha se limitaba a unos cuántos artículos en diarios y revistas, y a los catálogos de sus productos. No había ningún trabajo académico que abordara de forma sistemática tanto las distintas fases de su historia como el desarrollo de su producción.

Con esta nueva contribución podemos afirmar que la historia de esta empresa artística española está escrita en sus aspectos más relevantes, aunque, dada su larga vida, hay muchas particularidades de su variada producción aún sin investigar.

Sigamos, pues, la cronología de la Fundación para precisar algunos puntos del artículo que glosamos.

\section{Primer periodo: de 7 de febrero de 1941 a 4 de diciembre de 1962}

La Fundación comenzó su existencia legal el 7 de febrero de 1941, fecha en que se firmó la escritura de constitución. En los Estatutos, que se unieron 
a la escritura, se disponía la existencia de un Patronato, que sería auxiliado en su labor por un Consejo de Administración y un Consejo Asesor Artístico. La primera reunión del Consejo de Administración se celebró el 26 de febrero de 1941 en la residencia del conde de Casal, Manuel Escrivá de Romaní, que era su presidente. Señalemos que Pedro Masaveu Massaveu no fue nombrado presidente de la Fundación hasta $1942^{5}$.

La gestión material del proyecto se encomendó a Bernardo Suárez Crosa, como gerente, y a Juan Eguiagaray Senárega, como jefe de producción ${ }^{6}$.

En los primeros tiempos la Fundación comenzó su actividad en varias sedes simultáneamente, distribuidas entre Madrid capital, el Monte de El Pardo y Alcalá de Henares.

En la capital ocuparon durante distintos periodos de tiempo los siguientes lugares:

- En el Palacio Real dos habitaciones frente a la escalera de Damas (desde 20 de enero de 1941), y el apartamento del duque de Génova (desde el 5 de marzo de 1941). Todos los gastos de mantenimiento fueron por cuenta de la Fundación. Ambos locales fueron abandonados, a petición del Patrimonio Nacional, en julio de $1942^{7}$.

- El hotel de la calle Velázquez 41 con vuelta a Hermosilla 29 (desde junio de 1941 a noviembre de 1947) ${ }^{8}$.

- Un piso en la calle Velázquez 46 (desde agosto de 1942 a junio de 1943) ${ }^{9}$.

En Alcalá de Henares:

- Una casa señorial del siglo XVII, propiedad de Suárez Crosa, situada en la calle Santa Úrsula números 5 y 5 bis (desde octubre de 1941 a octubre de 1947).

- Un local en la calle Escritorios número 9 (desde junio de 1941 al verano de 1942$)^{10}$.

- Algunas dependencias del antiguo convento del Carmen Calzado (desde el verano de 1942 al otoño de 1947). El convento de la Magdalena, cercano a la casa de Suárez Crosa en Alcalá de Henares, no fue sede de la Fundación, a pesar de que esta confusión se ha ido repitiendo.

En el Monte de El Pardo se habilitaron dos sedes, una en el paraje llamado de Fuentelarreyna ${ }^{11}$, y la sede principal que se construyó en Somontes, ambas sobre terrenos propiedad del Patrimonio Nacional:

- El solar de Fuentelarreyna, que tenía una extensión de 20 hectáreas, estaba arrendado desde antes de la Guerra Civil a Luis Herrero Bueno. Allí se había construido un restaurante, que fue destruido por hallarse en la línea del frente durante la contienda ${ }^{12}$. La Fundación llegó a un acuerdo con Luis Herrero, entregándole la cantidad de 112.500 pesetas en concepto de indemnización por los edificios arruinados, y se subrogó en el arriendo ${ }^{13}$. El Patrimonio Nacional aceptó el cambio de arrendatario y puso como condición 
que los edificios rehabilitados y los construidos de nueva planta por la Fundación revirtieran en beneficio del suelo al finalizar el arriendo $^{14}$. La primera fábrica de porcelana (que había organizado sus primitivas instalaciones en el hotel de la calle Velázquez) y las oficinas se instalaron en esta sede de forma progresiva a partir de la primavera de 1943. En 1958 abandonaron los edificios y cesaron en el arriendo a petición del Patrimonio Nacional, que acordó vender los terrenos a una inmobiliaria ${ }^{15}$.

- El Cuartel de Somontes. Estos terrenos del Monte de El Pardo, que estaban destinados desde la etapa de la II República al ensanche de la capital, estaban arrendados en 1941 a la Sociedad de Tiro de Pichón. La Fundación solicitó en noviembre de 1941 la cesión de una parte del terreno, para construir su sede definitiva, a la citada Sociedad, y esta accedió a la solicitud por acuerdo de su Junta General celebrada el 12 de enero de $1942^{16}$. El gerente de la Fundación, Suárez Crosa, se dirigió a continuación al Consejo de Administración del Patrimonio Nacional, que acordó ceder 63 hectáreas en usufructo a condición de que todas las construcciones revirtieran a Patrimonio Nacional al finalizar el acuerdo ${ }^{17}$.

El 9 de diciembre de 1944, ante la necesidad de solicitar créditos hipotecarios para finalizar la construcción de la nueva sede, la Fundación formaliza una petición de compra de tan sólo 23 de aquellas hectáreas, para poder ofrecer las garantías precisas a la entidad acreedora. El Patrimonio Nacional, después de consultas al Negociado de Rústica que fijó el precio de venta ${ }^{18}$, y apoyándose en lo dispuesto por el artículo $5^{\circ}$ de la Ley de 7 de marzo de $1940^{19}$, que permitía la enajenación previa autorización por Decreto, acuerda la operación. El 13 de diciembre de 1945 se publicó el preceptivo Decreto de autorización $^{20}$. La transacción se formaliza ante notario mediante contrato de compraventa $^{21}$. La adquisición fue posible gracias a la concesión de créditos hipotecarios por el Instituto Nacional de Industria.

Las obras de la sede principal, supervisadas directamente por Suárez Crosa que era ingeniero de profesión, se iban realizando a medida que se conseguía en los tiempos difíciles de la posguerra el hierro y el cemento necesarios para la cimentación. Los trabajos se ejecutaban por cuadrillas de albañiles contratados directamente por el gerente. El hallazgo de una veta arcillosa en el terreno animó a los consejeros a instalar una pequeña tejera que suministró todos los ladrillos necesarios. Para la cubierta y los forjados se contrató en mayo de 1943 a la empresa Obras y Forjados y en 1944 a la Fábrica de Mieres y a Fomento de Obras y Construcciones. (Fig. 1). En otoño de 1947 se trasladaron todos los talleres a la nueva sede, con la excepción ya mencionada de la porcelana y las oficinas que lo hicieron en 1958.

Los talleres que se pusieron en marcha desde los primeros días fueron los siguientes: alfombras, tapices, bordados y ornamentos litúrgicos, tejidos, reposteros, porcelana (horno y decoración), ebanistería y tapicería, hilatura de lana y seda, tinte, escultura y talla, bronces, cristal y sección de proyectos de decoración; además hubo talleres de restauración de muebles, relojes, alfombras y tapices. Entre los talleres que no llegaron a instalarse, aunque se consideró su creación, se encontraban el de reproducciones artísticas y el de encuadernación (Fig. 2). 


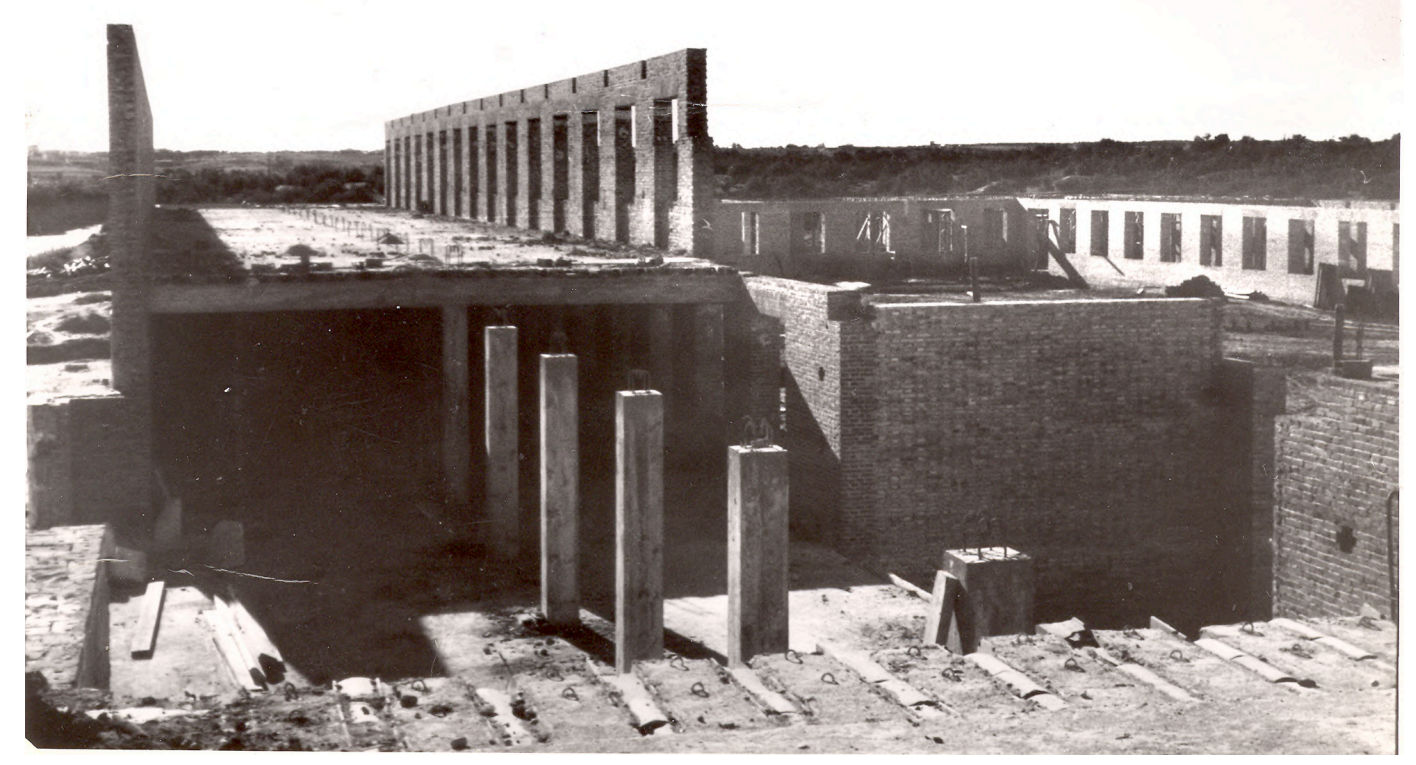

Fig. 1. La sede de El Pardo en construcción. 1944. Archivo Sánchez-Molero.

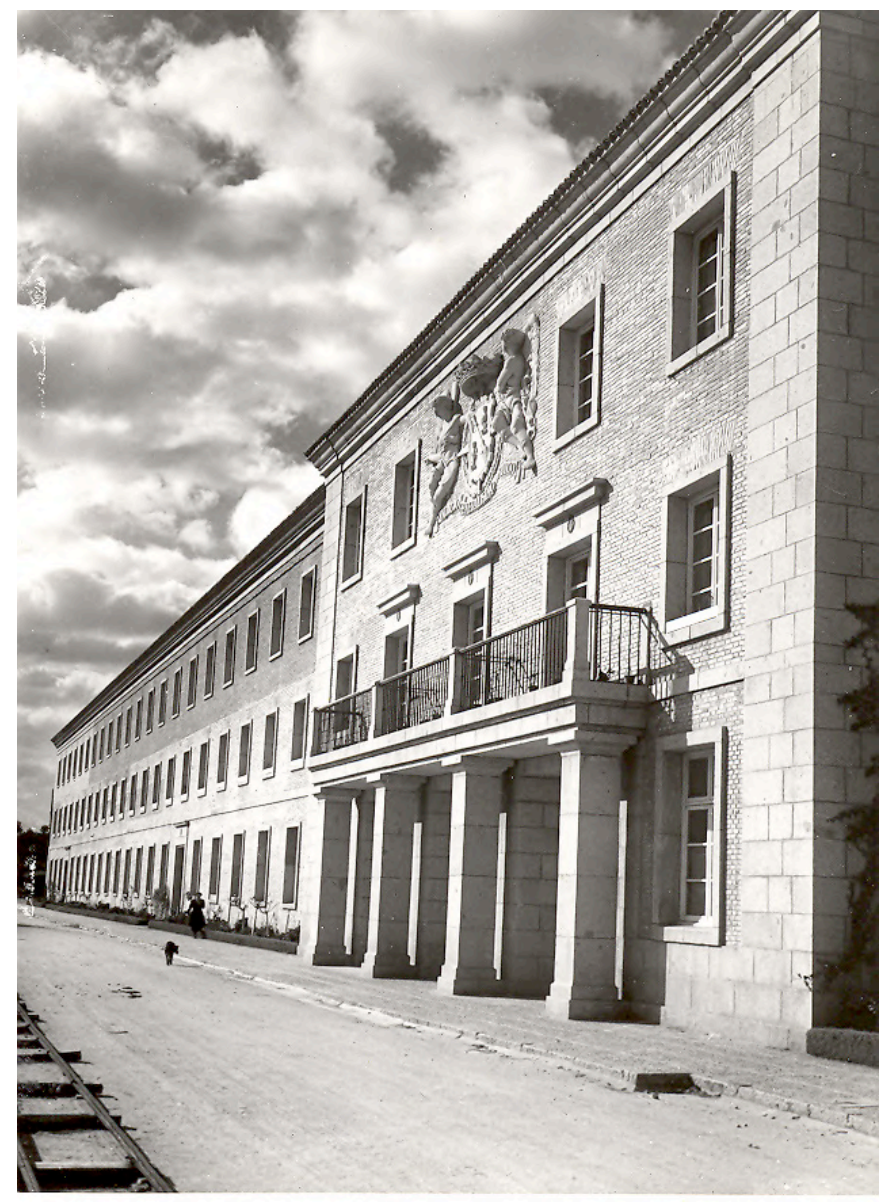

Fig. 2. Fachada principal de la sede de El Pardo. 1947. Archivo Sánchez-Molero. 


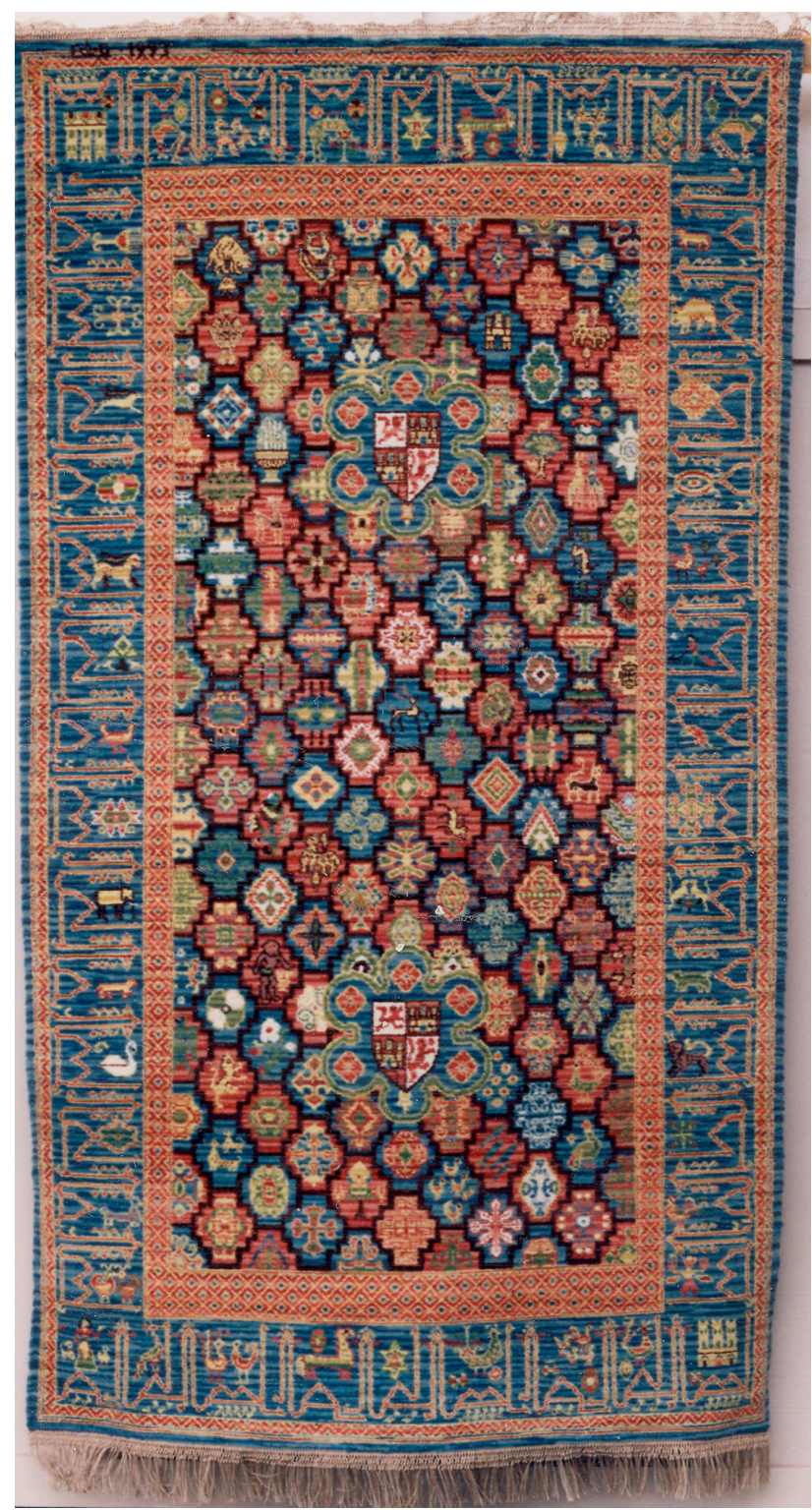

Fig. 3. Alfombra de nudo español. Archivo Sánchez Molero.

El personal integrante de los talleres era de distinta procedencia, la mayoría profesionales libres (algunas mujeres de la Sección Femenina) y cierto número de trabajadores penados. Estos últimos se incorporaban acogiéndose a la Orden de 1938 que creaba el Patronato para la Redención de Penas, donde se disponía la forma de condonación de la pena temporal, así como las condiciones salariales. En el caso de que los reclusos trabajasen para patronos de obras particulares (como los empleados de la Fundación), serían los patronos los obligados a pagar tanto los salarios, según las bases que regían en la localidad para trabajadores libres, como los seguros sociales ${ }^{22}$. La pérdida de parte del archivo documental de la Fundación no permite saber con exactitud el número de penados que trabajaron en los diferentes talleres, pero ha quedado un dato, esclarecedor de la contabilidad que se llevaba de los salarios devengados por los reclusos acogidos al programa de redención de penas: a 14.241,20 pesetas ascendieron las retribuciones de los que trabajaron en la rehabilitación de la sede de Velázquez $41^{23}$. Algunos de estos empleados dejaron la Fundación 
al redimir su condena, como ocurrió con los primeros artesanos del taller de metalistería, otros en cambio permanecieron en sus puestos de trabajo, ya como empleados libres, hasta el final de su vida laboral.

Durante esta primera etapa la actividad de los talleres es asombrosa, no sólo por la cantidad de proyectos acometidos sino también por su calidad y variedad. Además de su propósito de recuperar las artes decorativas de tradición española, como por ejemplo las alfombras de Alcaraz y Cuenca (Fig.3), los muebles inspirados en modelos históricos como los de la Magistral de Alcalá, los tejidos de seda, los reposteros heráldicos o los bordados como la réplica de la capa de Daroca (Fig. 4), se incorporaron diseños de una modernidad extraordinaria. Así en el taller de tapices, integrado exclusivamente por mujeres y dirigido por Petra Salgado, se tejieron modelos tan audaces como Los músicos ${ }^{24}$, sobre un cartón de Francisco Capulino, conocido en el mundo artístico como Capuleto, o el grandioso La toma de Granada por los Reyes Católi$\cos ^{25}$ sobre modelo de Carlos Sáez de Tejada, que emparenta con los proyectos franceses y belgas del momento y compite ventajosamente con ellos. Pero habría que aludir también a la novedad de reposteros como La batalla medieval $^{26}$ comprado por el Instituto Nacional de Industria, o la serie de Las Bellas Artes. En el taller de ebanistería, que en los primeros tiempos fabricó todos los telares, muebles y enseres necesarios para los talleres y despachos de la Fundación, se hicieron otras muchas obras como, por ejemplo, las puertas del templo de Santa Gema en Madrid y, naturalmente, los muebles de todos los proyectos de decoración. Esta última sección realizó numerosos diseños, un ejemplo más entre muchos fue el salón de actos del Ministerio de Justicia (Fig. 5); el espaldarazo definitivo lo obtuvo con la decoración completa del Hotel Castellana Hilton en 1952.

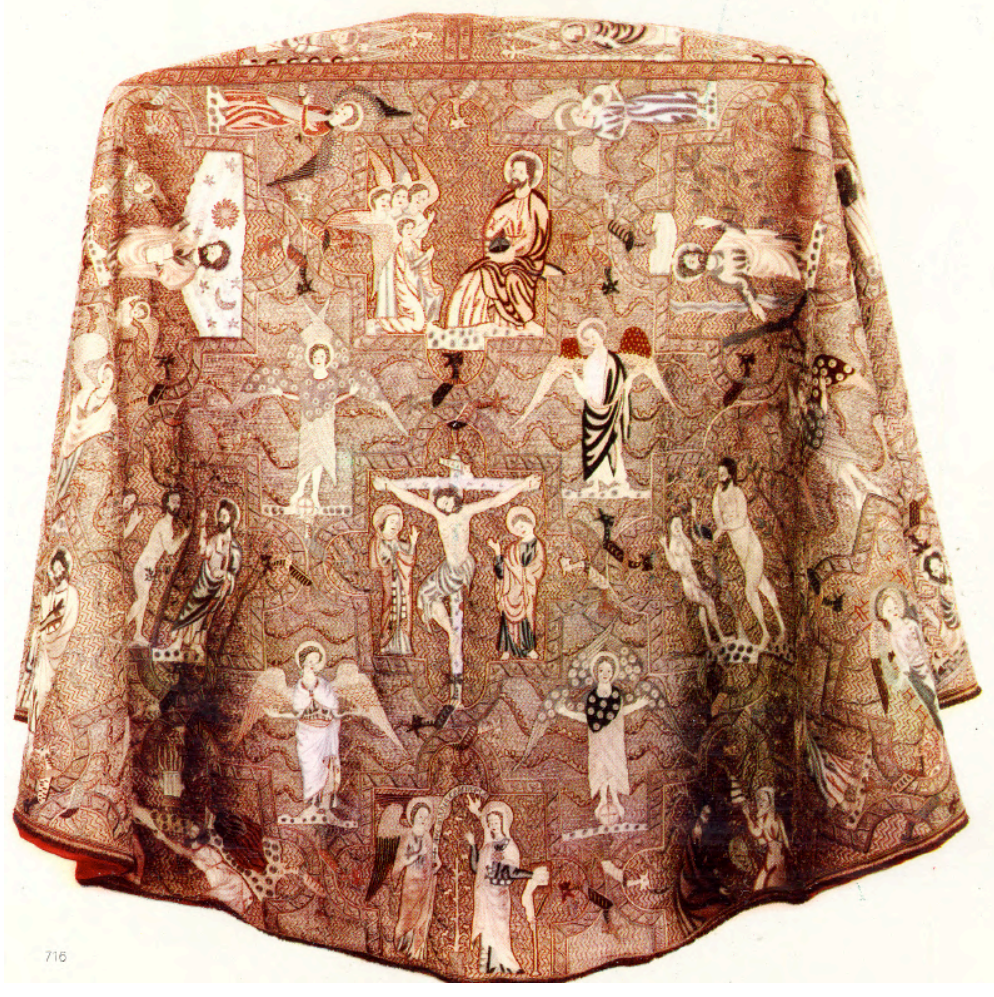

Fig. 4. Réplica de la capa de Daroca. Archivo Sánchez-Molero. 


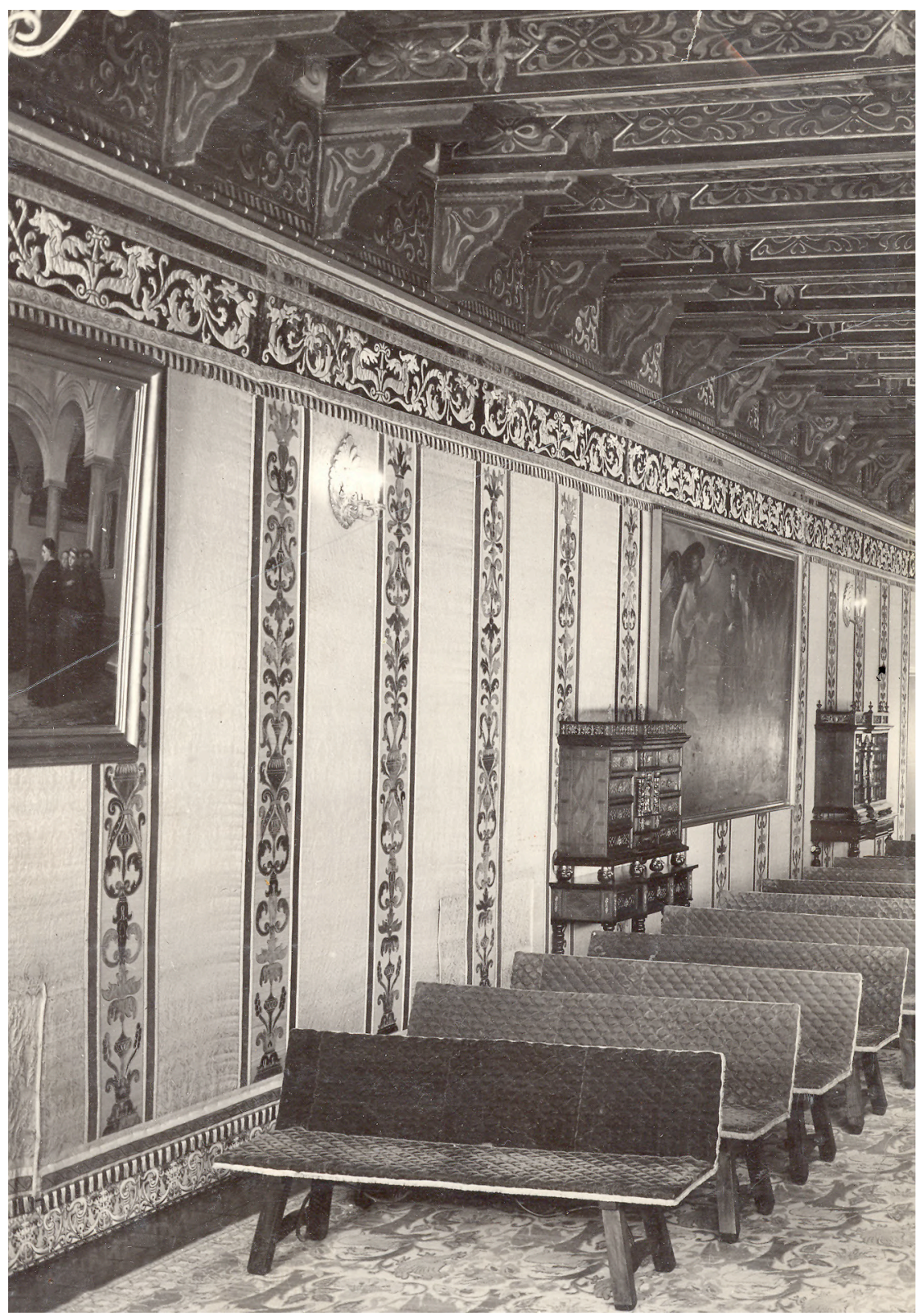

Fig. 5. Salón de actos del Ministerio de Justicia. Archivo Sánchez-Molero.

Un brevísimo comentario sobre el taller de porcelana. Se llegó a considerar seriamente la compra de una mina de caolín en la provincia de Toledo ${ }^{27}$ para tener asegurada la materia prima. El gerente, utilizando sus vacaciones y a su propia costa, hizo algunos viajes a distintas fábricas; posteriormente, con el apoyo económico de la Fundación, viajó a Francia, visitando Sèvres y Limoges, y también visitó fábricas de Alemania, Bélgica, Suiza, Italia y Portugal, para conocer de primera mano los procesos de fabricación y la maquinaria empleada ${ }^{28}$. Para garantizar resultados excelentes en la elaboración de pasta blanca, se llegó a colaborar con el CSIC en $1955^{29}$. En abril de 1942 se tienen los primeros contactos con especialistas franceses a los que se propone venir a España: en Limoges se mantienen conversaciones con Mr. Blancher con vistas a contratarlo como Jefe de fabricación, pero no se llega a sustanciar el acuerdo ${ }^{30}$; para la sección de decoración de porcelana se contrata en mayo del mismo año a Mr. Molho, profesional de La 
Porcelaine de Paris, quien viene a España acompañado de su ayudante Mr. Pietri $^{31}$. La primera maquinaria procedente de Francia, de la casa Faure y C. de Limoges, llegó a España en esas mismas fechas. En cuanto a la materia prima, la pasta blanca, se fabricó en parte en el embrionario laboratorio de la Fundación, pero con el aumento de la demanda de sus productos se hizo necesario adquirir cierta cantidad a otros suministradores; en distintos momentos se compró en Francia, a través del Sindicato de fabricantes de porcelana de Limoges, en Portugal y en la propia España, mediante un acuerdo con la Fábrica de Porcelanas de Bidasoa. Hay que señalar un hecho de gran importancia artística: la antigua Fábrica de Alcora, fundada en 1727 por el conde de Aranda, cierra después de que sus últimos propietarios hubieran intentado reflotarla sin éxito; en 1952 ponen a la venta su colección de matrices, más de trescientas; la Fundación la adquiere, cumpliendo de este modo con otro de sus fines, el de continuar la tradición española también en el caso de la porcelana ${ }^{32}$.

En 1958, coincidiendo con la reunión de todos los talleres y oficinas en el edificio principal, se contrató a José Luis Miranda, marqués de Miranda, como director artístico, aunque sin prescindir del Consejo Asesor. Su influencia se hizo notar inmediatamente con la introducción de los estilos inglés y francés en el taller de ebanistería; con los ensayos para la obtención del color sangre de toro en el taller de porcelana, ensayos que culminaron con éxito, pese a la dificultad del proceso; y el diseño de nuevos modelos de reposteros basados en la estilización de jarrones, animales y flores. Las nuevas líneas de producto tuvieron gran desarrollo en la etapa siguiente.

Tampoco se descuidó la organización comercial, como demuestra la edición de catálogos (uno de ellos, de muebles, en inglés para compradores norteamericanos); la participación en ferias nacionales e internaciones, como la de Nueva York; la apertura de locales destinados a la exhibición de sus productos, el primero en las dependencias del antiguo convento del Carmen Calzado de Alcalá de Henares en 1942; la compra en dos etapas (1945-1946) de Nájera, espléndido local situado en la plaza de la Independencia; la habilitación de dos espacios de mil metros cuadrados en las plantas segunda y tercera del edificio de Somontes a partir de 1958; la inauguración de un espacio comercial en el hotel Castellana Hilton, donde se alojaban la mayoría de los visitantes norteamericanos que llegaban a España en aquellos años, y que se convirtieron en buenos clientes. Para abrir nuevos cauces se colaboró con el Banco Exterior de España, la Cámara de Comercio española en Suiza, la Sociedad de Importadores de Café y la Sociedad Hispanoamericana de Importaciones. Merece comentario aparte la Exposición Flotante del buque Ciudad de Toledo ${ }^{33}$, que en 1956 recorrió más de treinta puertos de España, norte de África y América, siendo visitado por dos millones y medio de personas; fueron mil doscientos los expositores representantes de todas las ramas de la industria española, distribuidos en distintas secciones; en los sectores n. ${ }^{\circ} 11$ (Galería de Arte) y n. ${ }^{\circ} 14$ (Varios) figuraba la Fundación, entre cuyos productos exhibía magníficas obras como el repostero Ciudad de Toledo ${ }^{34}$ (Fig. 6) y la réplica de la capa de Daroca ${ }^{35}$. 


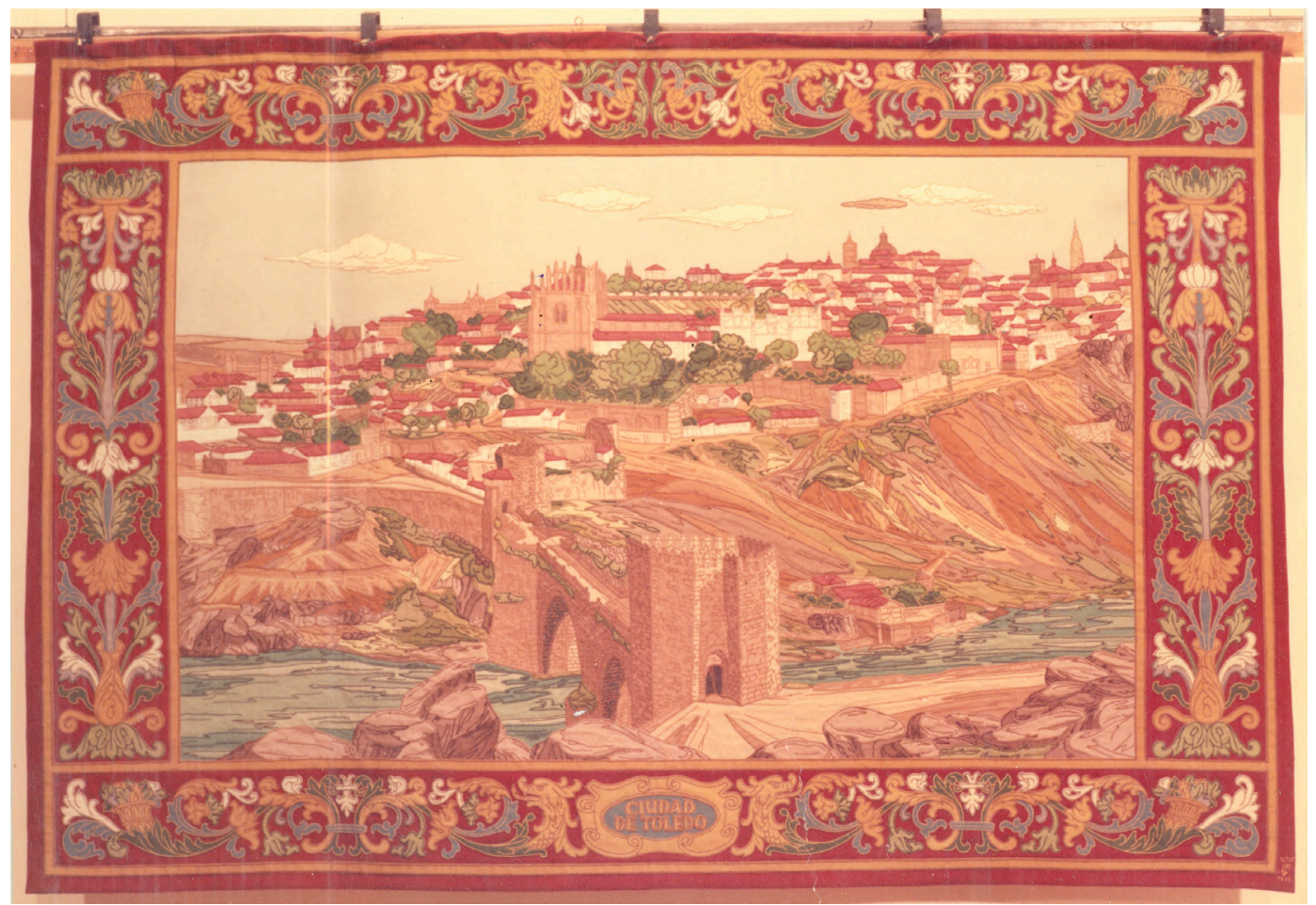

Fig. 6. Repostero Ciudad de Toledo. Archivo Sánchez Molero.

Un aspecto cardinal de la Fundación fue su propósito social. Conforme a lo dispuesto en los Estatutos, el 85\% de los beneficios debía destinarse "a la ampliación de las industrias que necesiten ser perfeccionadas o creadas y a propulsar y premiar al personal técnico y obrero, así como a instituir obras sociales" ${ }^{36}$. A este principio respondía la apertura de pequeños talleres artesanos en distintos puntos de España y el reparto anual de beneficios ${ }^{37}$. Pero la obra social de mayor envergadura fue la creación del poblado de San Francisco, compuesto por viviendas, escuela, parroquia, campos de deporte y economato, destinado a los empleados y levantado en las proximidades de la fábrica. El proyecto se desarrolló en dos fases: la primera comienza en enero de 1942, a tan solo once meses de la constitución de la Fundación, con las gestiones iniciales ordenadas a la compra de varias parcelas en los vecinos municipios de Fuencarral y Peña Grande, cerca del monte de El Pardo pero al otro lado de la valla, hasta reunir ochenta mil metros cuadrados. Es preciso insistir en que el poblado de San Francisco se levantó sobre terrenos propiedad de la Fundación, adquiridos mediante contrato de compraventa y no por expropiación forzosa. El Consejo de Administración había barajado varias posibilidades para la adquisición de los terrenos ${ }^{38}$, pero fue finalmente la propia Fundación la que realizó la compra de los solares. El arquitecto Menéndez Pidal fue autor de los planos de esta primera fase ${ }^{39}$. Desde febrero de 1944 funcionó un Consejo auxiliar técnico, para supervisar la construcción del poblado, compuesto por: José María Gutiérrez Pajares, ingeniero de caminos; Gabriel Rodríguez del Palacio; Luis Casanova; Bernardo Suárez Crosa y el secretario general del Consejo de Administración, marqués de Colomina ${ }^{40}$. Para adjudicar la construcción, la Obra Sindical "Artesanía" convoca un concurso al que se presentan tres contratistas además de la propia Fundación, a quien 
finalmente se le asigna por ofrecer el precio más ajustado, ya que disponía de una tejera propia en las cercanías y la maquinaria de construcción que se estaba utilizando para levantar la Fábrica. Las obras comenzaron el 1 de marzo de 1945. La segunda fase se inició en mayo de 1947; el arquitecto responsable fue Eduardo Olasagasti Irigoyen. En torno a este proyecto se generó una documentación muy interesante, que pone de manifiesto los propósitos sociales que orientaban la actividad de la Fundación ${ }^{41}$.

La financiación, un asunto de gran trascendencia al que también alude la doctora Fernández, se solucionó inicialmente con los 4.000 .000 de pesetas que aportó el propio fundador. Los consejeros convirtieron de inmediato 3.500.000 de pesetas en Bonos del Tesoro y abrieron dos cuentas en el Banco Español de Crédito para ingresar el medio millón restante, con el que atender a las primeras necesidades ${ }^{42}$. Durante los primeros tiempos se sufragaron los gastos con las sucesivas ventas de Bonos del Tesoro y con los ingresos obtenidos por la comercialización de sus productos (las primeras facturas son de diciembre de 1941). Otro medio de financiación fue las aportaciones de los patronos en distintos momentos; con respecto al donativo hecho en 1943 por Demetrio Carceller, ministro de Industria, al que se refiere la doctora Fernández en su artículo, hemos de señalar que se hizo a título personal, como se consigna en el acta de la sesión del Consejo de Administración de 13 de agosto de aquel año ${ }^{43}$; por otra parte, es de justicia insistir en que la naturaleza del Patronato es la asistencia y protección, también económica, del patrocinado, por tanto nada tiene de extraña la aportación pecuniaria de los miembros, que durante los veintiún años de esta primera etapa de la Fundación ascendió a 3.449.863,09 de pesetas. También se recibía una pequeña subvención del Ministerio de Educación, cuyo importe exacto desconocemos, con la que se sufragaba parte de la formación profesional. Pero la fuente más importante de financiación fueron los préstamos con garantía hipotecaria que concedió el Instituto Nacional de Industria, y que ascendieron a 33.000.000 de pesetas ${ }^{44}$.

En 1950 se produce el primer cambio de importancia en la organización interna, cesan Bernardo Suárez Crosa como director general y Andrés Ruiz Pla como gerente ${ }^{45}$, en sustitución se nombra a Luis Auguet Durán (que era director de la Casa de la Moneda) con el cargo de vicepresidente del Consejo y funciones de director gerente. Entran a formar parte del Consejo dos nuevos miembros, Jesús Romeo Gorría y Fernando Puertas Gallardo. Auguet hace una reorganización de servicios, toma medidas para la contención del gasto y procede a vender algunos terrenos propiedad de la Fundación para resolver los problemas de caja ${ }^{46}$. A pesar de todo las dificultades financieras siguen acuciando a la Fundación, de manera que el nuevo director se manifiesta partidario de solicitar consignaciones estatales, como ocurría con la manufactura de Sèvres que era sostenida por el Estado francés. Esta solución choca con el espíritu de independencia con la que había nacido la institución y su carácter privado, así que muchos consejeros se declaran contrarios; pero en 1959, algo desalentados por las necesidades económicas que no acababan de solventarse, elevan un informe al fundador donde se reconocía la necesidad de recurrir a las subvenciones. Este estaba bien enterado de la situación a través de los balances anuales y de los informes independientes que recibía, de ellos se desprendía que en 1949, a pesar de los enormes gastos de instalación, la Fundación tenía un superávit de dos millones de pesetas y, sin embargo, en 
1959 la pérdida rondaba los treinta millones ${ }^{47}$. En mayo de 1962 una comisión de la Fundación es recibida en audiencia por el jefe del Estado; no hay constancia documental de lo que allí se habló, pero las decisiones posteriores parecen confirmar que Franco comunicaría su determinación de cambiar la naturaleza jurídica de la institución para preservar los más de seiscientos puestos de trabajo directo y los numerosos talleres rurales que dependían en cierto modo de ella.

\section{Segundo periodo: de 4 de diciembre de 1962 a 20 de noviembre de 1975}

El 4 de diciembre de 1962 se modifican los Estatutos de la Fundación, que a partir de ese momento se integrará en el Patrimonio Nacional, encomendándose la gestión al Consejo de Administración del mismo ${ }^{48}$. Se perdía así el carácter privado pero se aseguraba su continuidad sin inquietudes económicas.

Coincidiendo con la reorganización emprendida en 1958 por el nuevo director artístico, José Luis Miranda, se diseña el magnífico jardín y la verja que rodeará el terreno de la sede (Fig. 7 y 8). En 1966 se contrata como ayudante de Miranda a Galo Brull Lenza que, al fallecer aquel poco después, le sustituirá en el puesto. Brull permaneció en el cargo hasta 1981, y a él se debe la continuidad y éxito de las iniciativas de Miranda, así como muchos nuevos diseños de porcelana, talla, reposteros, etc.

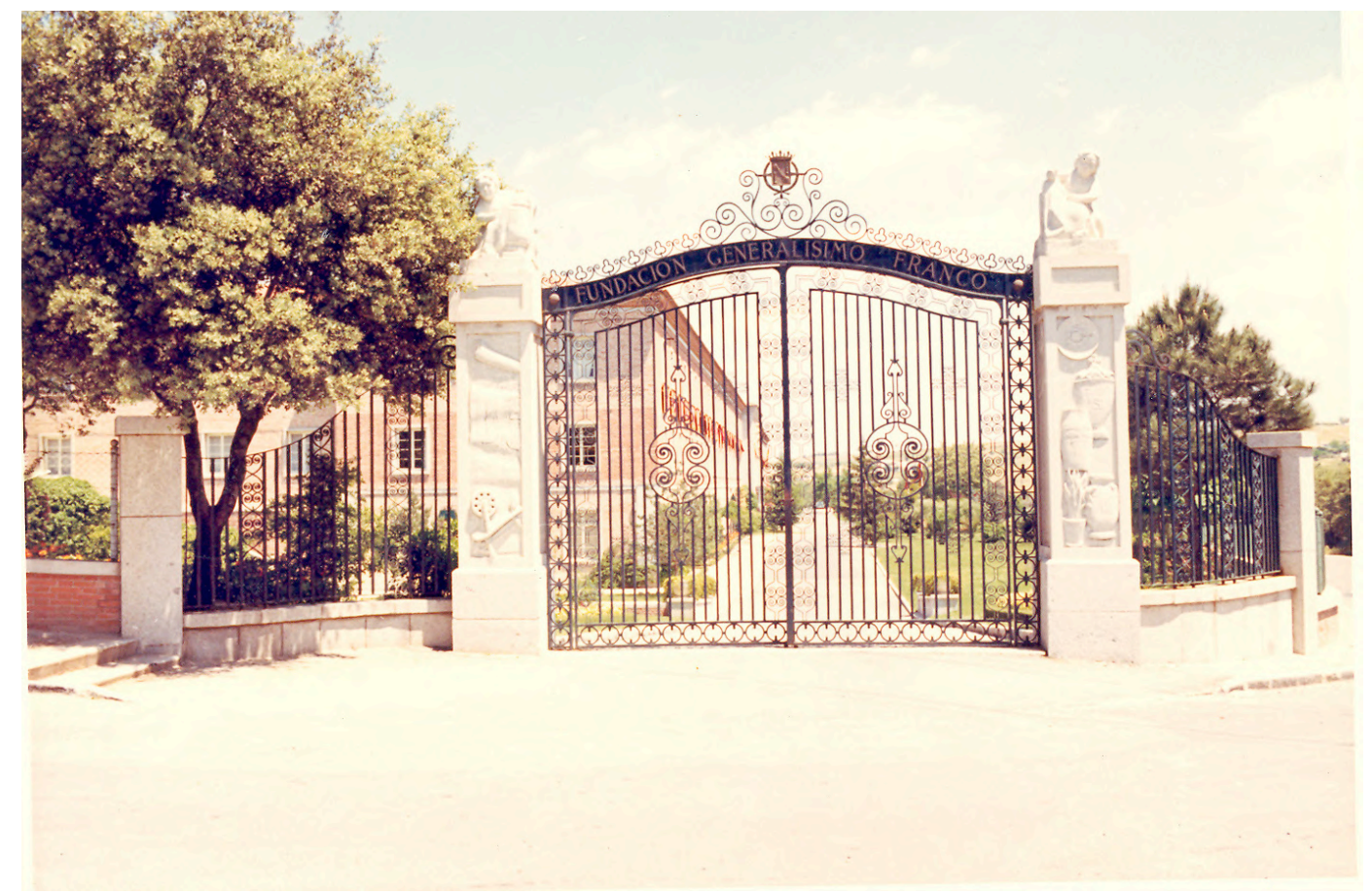

Fig. 7. Verja de acceso. Sede de El Pardo. Archivo Sánchez Molero. 


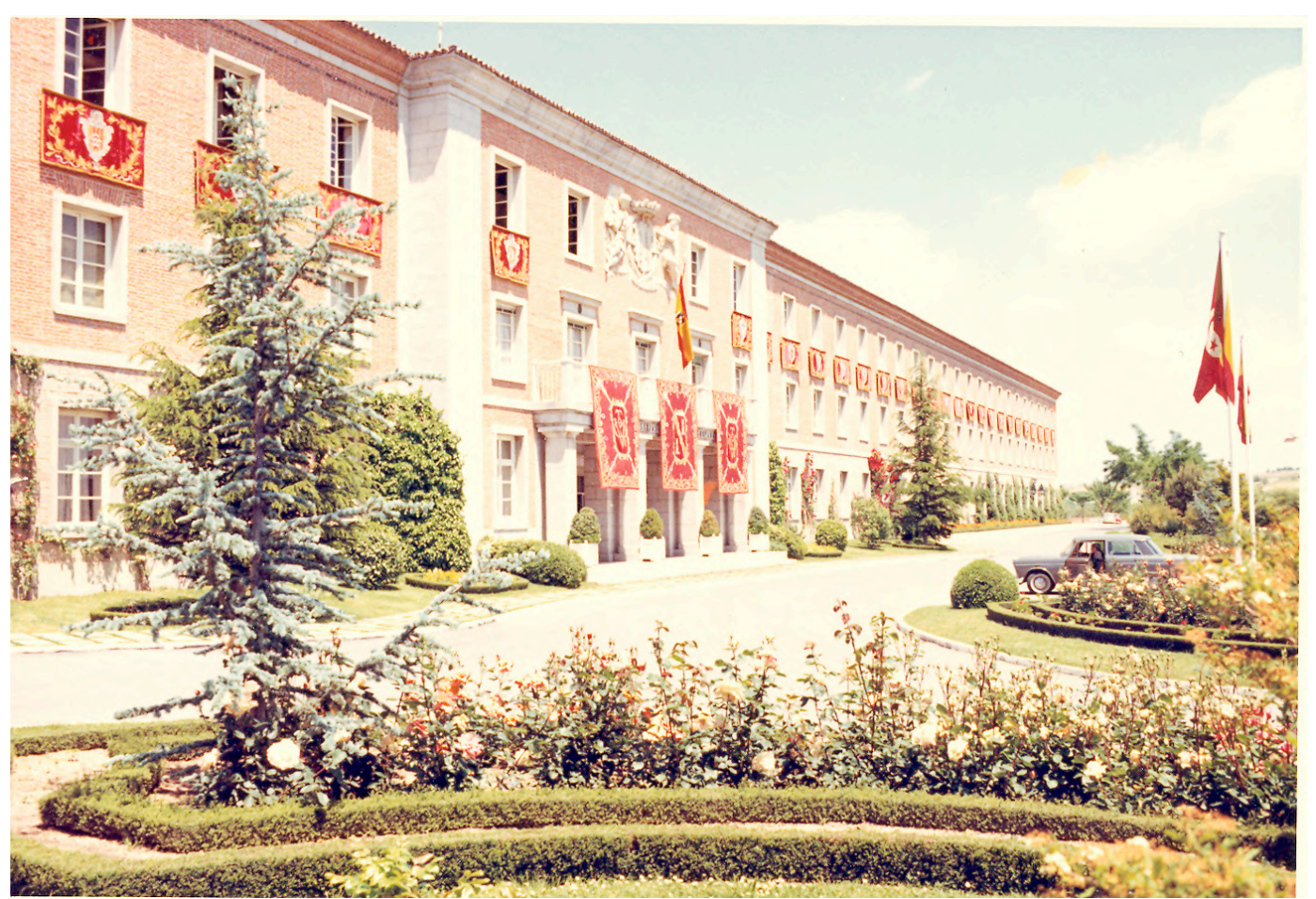

Fig. 8. Fachada principal engalanada. Archivo Sánchez-Molero.

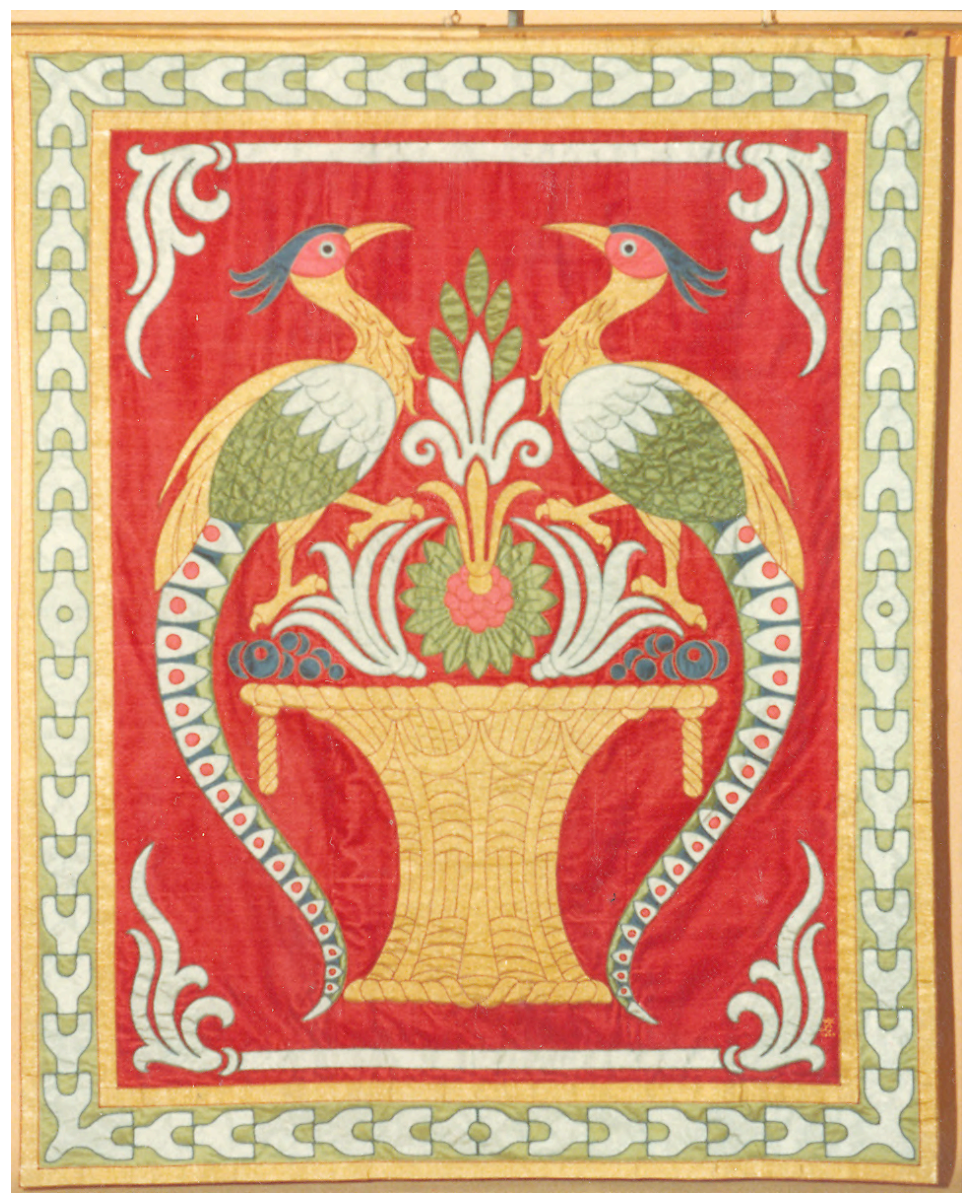

Fig. 9. Repostero. Archivo Sánchez Molero. 
Los talleres alcanzan en esta etapa su máximo desarrollo. En el de alfombras se fabrican importantes encargos como el del palacio presidencial de Malta. El de tejidos recuperó los tradicionales espolines, brocateles y terciopelos de seda, pero también se diseñaron nuevos modelos inspirados en ejemplares históricos. El de reposteros se consagró como un gran especialista en temas heráldicos y vestiduras de mesas, pero también confeccionó reposteros con escenas diversas como el encargado por el Ministerio de Marina. Una novedad, introducida por Miranda, que tuvo mucho éxito comercial, fue el nuevo tipo de reposteros a los que nos hemos referido más arriba (Fig. 9).

$\mathrm{Al}$ taller de tapices se incorporan por primera vez algunos tejedores procedentes de la Real Fábrica de Tapices, atraídos por las mejores condiciones salariales y por los beneficios sociales que ofrecía la Ordenanza Laboral. La obra magna de este taller durante este segundo periodo es la réplica de los tapices del Apocalipsis de San Juan, serie flamenca del siglo XVI encargada por Felipe II y conservada en el palacio de San Ildefonso de la Granja. Resumamos muy brevemente la génesis de esta grandiosa réplica, destinada al ornato de la Basílica del Valle de los Caídos, que fue tejida entre noviembre de 1964 y diciembre de 1975. En la decoración interior de la Basílica participaron artistas españoles de todas las especialidades (escultura, mosaico, rejería, talla, policromado, pintura, bronces). Para cubrir los muros de la nave de ingreso se pensó desde el principio en los tapices y por ello se convocó un concurso para el diseño de los cartones. Queda constancia del proyecto presentado por la Real Fábrica de Tapices, consistente en ocho cartones que desarrollaban el tema de la guerra civil española, centrado cada uno de ellos en una importante batalla, localizaba en escenarios reconocibles de la geografía española ${ }^{49}$. También se conocen los bocetos presentados por Juan Antonio Morales, sobre acontecimientos importantes de la historia de España ${ }^{50}$. Sin embargo el concurso quedó en suspenso y, mientras se decidía sobre este punto, por sugerencia del marqués de Lozoya se colgaron en los ochos entrepaños de la nave los tapices del Apocalipsis de San Juan confeccionados en el siglo XVI. De la operación de traslado e instalación se ocupó la Real Fábrica de Tapices. La serie flamenca estuvo en ese emplazamiento entre 1957 y $1975^{51}$. También la Real Fábrica se encargó de colgar la nueva serie (única réplica existente hasta la fecha de los tapices del siglo XVI) en el mismo lugar; a ambos lados de cada uno de los nuevos paños, se colocaron unas cenefas tejidas en el siglo XVIII en la propia Real Fábrica. Tanto las cenefas del siglo XVIII como los tapices de la Fundación continúan en el mismo lugar actualmente.

El taller de porcelana sufrió algunas variaciones en esta segunda etapa: la sustitución de los hornos de leña por otros alimentados por propano o por electricidad. También sus modelos cambiaron bajo la influencia de Miranda; se hicieron lámparas de porcelana que tuvieron muy buena acogida comercial y se logró por primera vez en este taller, como antes hemos apuntado, el color sangre de toro. En el departamento de muebles, sin renunciar a nuestros muebles históricos, se introdujeron los estilos francés e inglés (Fig. 10). Otro taller que alcanzó un gran desarrollo fue el de metalistería: rejas, puertas, ventanas, faroles, lámparas, etc., elaborados artesanalmente con fragua, martillo y yunque; la verja de la sede fue diseñada y construida por los artesanos de la Fundación. El de vidrieras, aunque era el menos desarrollado, hizo también una estimable labor, destaca entre todas sus obras la reproducción de las vidrieras de la catedral de León. Entre los proyectos decorativos completos podríamos añadir a 
los citados por la doctora Fernández, la residencia de los entonces Príncipes de España y la residencia privada de Balduino y Fabiola de Bélgica.

En 1969 se publica Ordenanza Laboral de la Fundación y el Reglamento que desarrolla su contenido ${ }^{52}$.

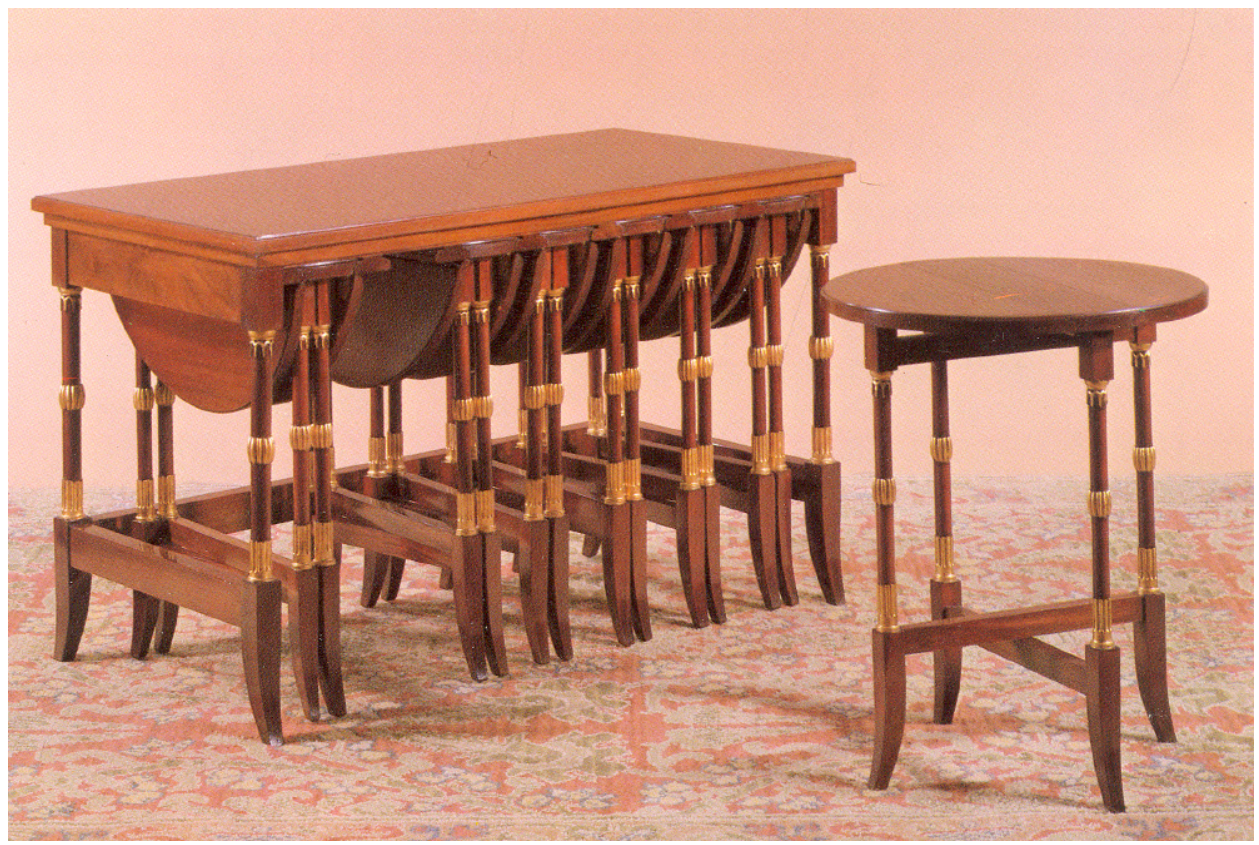

Fig. 10. Mesitas nido. Archivo Sánchez-Molero.

\section{Tercer periodo: de 20 de noviembre de 1975 a 15 de junio de 1995}

Con la muerte de Franco, el 20 de noviembre de 1975, se inicia una transformación política que conducirá a España hacia la democracia parlamentaria. Sin embargo este hecho no supondrá ningún cambio en la naturaleza jurídica de la Fundación, que seguirá integrada en el Patrimonio Nacional dependiendo directamente del rey, que asumía automáticamente las funciones relacionadas con los Patronatos integrados en aquel ${ }^{53}$. Sin embargo la crisis económica de aquellos años sí afectará negativamente a la fábrica, ya que los capitales se retraen y, en consecuencia, los pedidos de particulares desaparecen. Afortunadamente los encargos oficiales para remodelar el palacio de la Moncloa y transformarlo en la residencia del presidente del gobierno; la decoración del pabellón de invitados del palacio de La Zarzuela; la decoración del palacio de El Pardo como nueva residencia de presidentes extranjeros en visita oficial, y la reforma del Consejo de Estado para adecuarlo a su nueva función como sede del Senado, permitieron cierta holgura en el departamento de decoración. También ayudaron en esta difícil situación económica, los encargos que se recibieron desde los Emiratos Árabes y Arabia Saudita.

Los primeros cambios en la organización interna se produjeron en 1978, momento en que se contrata a Muntañola Tey como director comercial, y a Lorenzo Ramos-Paúl como director ejecutivo. Entre este último y Galo Brull no nace buen entendimiento, lo que provoca la dimisión de Brull en 1981. Este hecho es un signo de que se está cerrando definitivamente una época. 
Los asuntos relacionados con el estatuto jurídico de la Fundación despiertan un gran interés en medios políticos ya desde 1977, año en que se legaliza la Asociación de Defensa Ecológica y del Patrimonio Histórico-Artístico, activa desde $1976^{54}$. En 1979 la Asociación emite un informe en relación con el proyecto de una nueva Ley reguladora del Patrimonio Nacional, en el que se señala como imprescindible la supresión de la Fundación ${ }^{55}$. El 14 de noviembre de 1980 Presidencia del gobierno remite al Congreso para su discusión el proyecto de una nueva Ley reguladora del Patrimonio; del listado de patronatos se había suprimido la Fundación, que estaba incluida desde $1962^{56}$. En 1981 el Grupo Parlamentario Socialista, a través de su portavoz Enrique Barón Crespo, formula dos preguntas en el Congreso de los Diputados en relación con la Fundación: el 16 de febrero ${ }^{57}$ (dirigida al gobierno de Unión de Centro Democrático, sobre gestión, estado patrimonial y criterios del gobierno sobre la inclusión o exclusión de la Fundación en el Patrimonio Nacional) y el 26 de octubre ${ }^{58}$ (dirigida al gerente del Patrimonio Nacional, sobre la vinculación entre este y la Fundación). Las respuestas verbales de Ramón Andrada Pfeiffer, gerente del Patrimonio, y el informe emitido por la Presidencia del Gobierno el 9 de febrero de $1982^{59}$, constituyen el punto de arranque de las transformaciones legales que sufrirá la Fundación en los años sucesivos. La Ley 23/1982, de 16 de junio, reguladora del Patrimonio Nacional, consagra el contenido del proyecto de 1980, ya que en su artículo 5. ${ }^{\circ}$ no aparece la Fundación como uno de los Patronatos ${ }^{60}$. Los empleados de la Fundación comprenden perfectamente lo que esto supone y comienza una lucha por la supervivencia, que derivará en una dolorosa ruptura con sus gestores directos. La aplicación efectiva de las disposiciones de la nueva Ley a la Fundación requería ciertas modificaciones estatutarias. La primera, de 22 de mayo de 1984, modificaba el artículo $5^{\circ}$, suprimiendo el párrafo en el que se disponía su integración como patronato dentro del Patrimonio Nacional ${ }^{61}$. El 28 de noviembre de 1984 una nueva modificación estatutaria afecta a los artículos $1^{\circ}, 2^{\circ}$ y $6^{\circ}$, que entre otras cosas cambia el nombre original por el de Fundación de Gremios; se crea un órgano de gestión que desempeñará las funciones asumidas hasta el momento por el consejo de Administración del Patrimonio Nacional y se acotan los límites de su cooperación, que quedará delimitada por la vía de convenio ${ }^{62}$. El temor fundado por la continuidad de la institución hace que los empleados pasen de elevar informes y peticiones ante sus órganos de gestión, a presentar reclamaciones ante la Audiencia Territorial de Madrid, la Magistratura de Trabajo y el Tribunal Supremo. Este último en sentencias de 21 de marzo de 1989 y 2 de octubre del mismo año declara que la Fundación tiene personalidad jurídica independiente del Patrimonio Nacional.

La organización interna se va a transformar poco a poco en un caos. En 1984 abandona el cargo de director ejecutivo Ramos-Paúl. Es sustituido por un Comité de Dirección provisional, que seis meses después cesa y traspasa sus funciones a un Consejo directivo que no puede celebrar reuniones por falta de quórum; entre octubre de 1985 y marzo de 1987 no se celebra ningún Consejo. En estas circunstancias los jefes de taller asumen la gestión diaria sin ningún plan rector. Por fin se nombra un nuevo director ejecutivo, Fernando López Pardo, y el 7 de marzo de 1987 un nuevo Consejo presidido por Enrique del Moral Sandoval. Se presenta el primer presupuesto después de años sin hacerse y se solicita a dos empresas que presenten un plan de viabilidad. También se contrata como director artístico a Luis Caruncho y como jefe de producción a Antonio García (Fig. 11, 12, 13 y 14). 


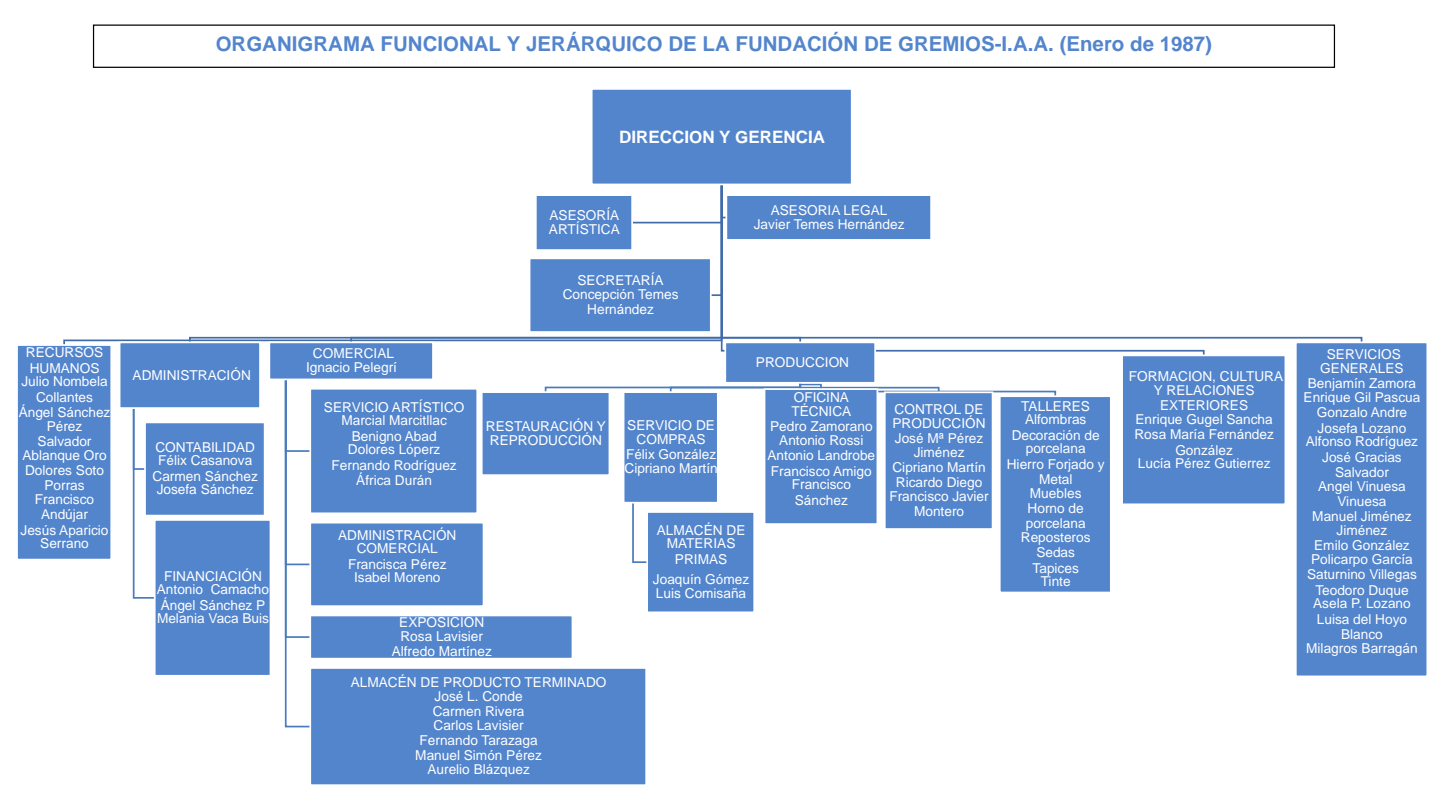

Fig. 11. Organigrama de enero de 1987. Confeccionado sobre datos del Archivo del Trabajo. Fundación $1^{\circ}$ de Mayo. Fondo documental de la Fundación de Gremios. Sig. 2/4.

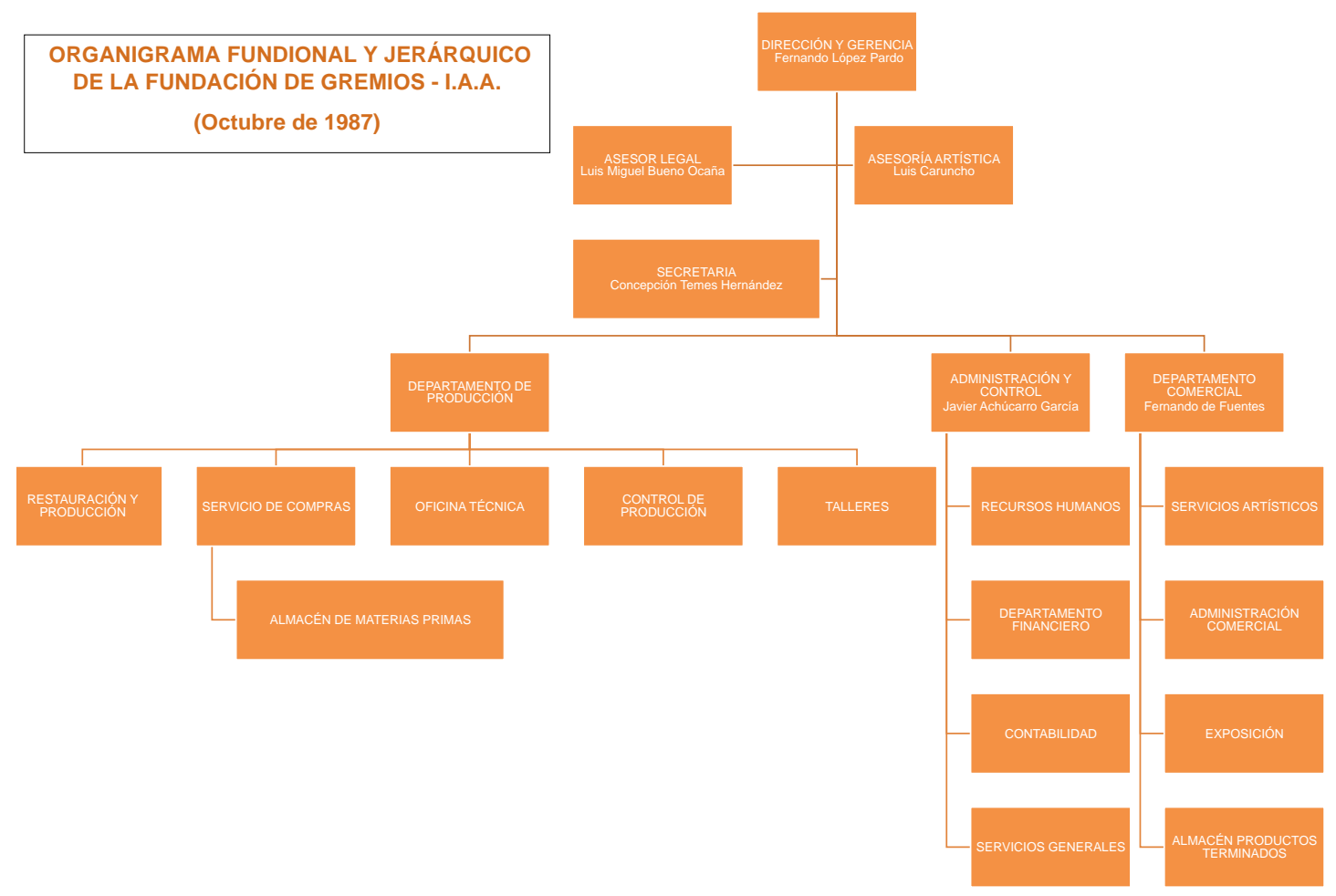

Fig. 12. Organigrama de octubre de 1987. Archivo del Trabajo. Fundación $1^{\circ}$ de Mayo. Fondo documental de la Fundación de Gremios. Sig. 2/4. 


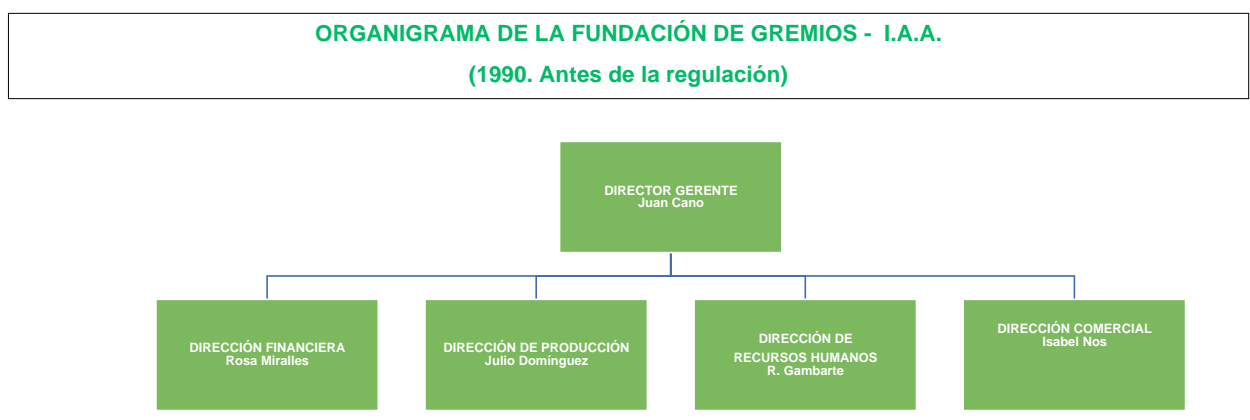

Fig. 13. Organigrama de 1990, antes de la reforma.Archivo del Trabajo. Fundación $1^{\circ}$ de Mayo. Fondo documental de la Fundación de Gremios. Sig. 2/4.

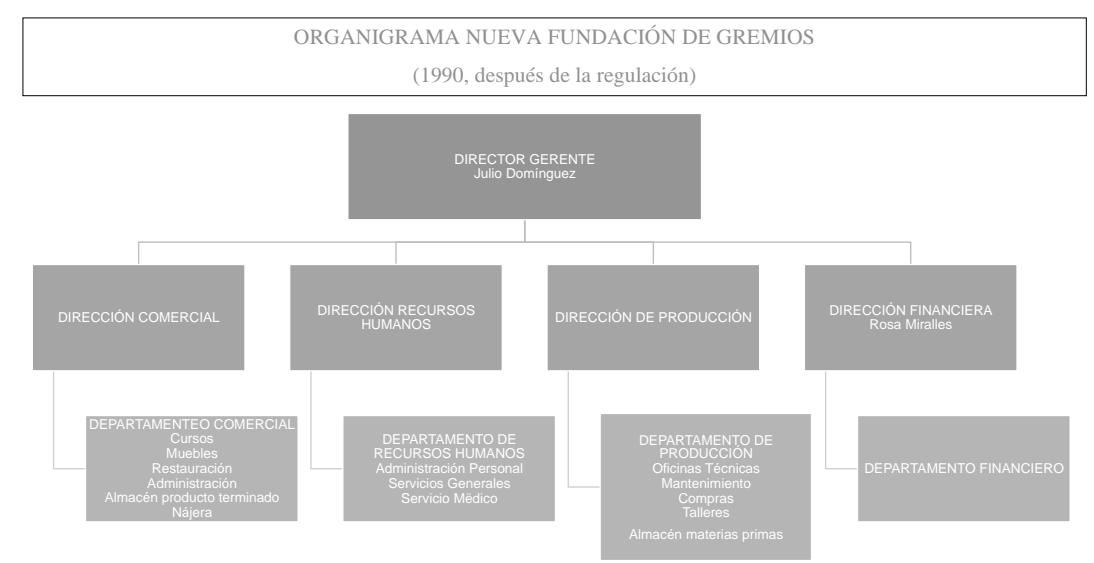

Fig. 14. Organigrama de 1990, después de la reforma. Archivo del Trabajo. Fundación $1^{\circ}$ de Mayo. Fondo documental de la Fundación de Gremios. Sig. 2/4.

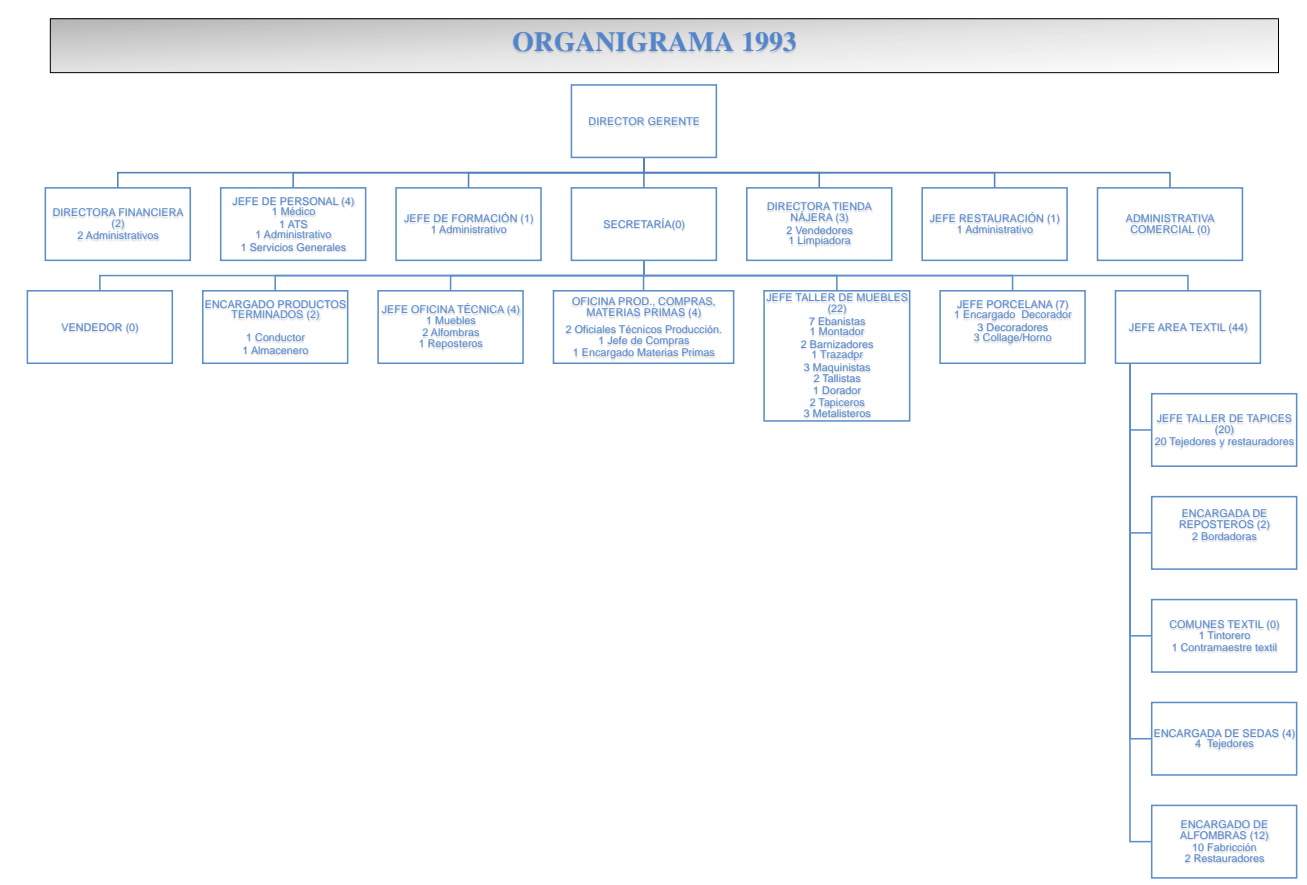

Fig. 15. Organigrama de 1993. Archivo del Trabajo. Fundación $1^{\circ}$ de Mayo. Fondo documental de la Fundación de Gremios. Sig. 2/4. 
Los frecuentes cambios en la dirección y la progresiva desorganización administrativa y económica impedían sostener un proyecto artístico a largo plazo. A pesar de ello se pusieron en marcha algunas iniciativas interesantes, como por ejemplo las del área textil ${ }^{63}$ : en el taller de tapices diseños de Joaquín Vaquero Turcios ${ }^{64}$ y de Eusebio Sempere ${ }^{65}$; en el taller de alfombras se tejió Cacería persa, alfombra de Mariscal destinada a la Generalidad de Valencia (Fig. 16); la obra de Mariscal es una mixtura entre alfombra de oración y diseños textiles persas, pasados por el tamiz de Hirozo Murata, el resultado de esta curiosa mezcla es muy decorativo. En el taller de reposteros se realizaron interesantes obras, como el telón del teatro Español de Madrid; los diseños de Galo Brull sobre naturalezas muertas, y una nueva serie de piezas sobre las Bellas Artes para el Auditorio Nacional de Música de Madrid. Señalemos en el taller de bordados la confección de las vestiduras de los maceros del Ayuntamiento de Burgos, inspiradas en las piezas medievales conservadas en el Monasterio de las Huelgas. El taller de restauración de tapices fue el responsable de la recuperación de series espléndidas pertenecientes al Patrimonio Nacional, como Los pecados capitales, La conquista de Túnez, Vertumno y Pomona y tantos otros; así como colecciones de la Iglesia, entre las que podemos recordar además de los tapices de Cornelius Schulz de la colegiata de Santa María del Manzano de Castrojeriz (Burgos), mencionados por Ana María Fernández, los de la parroquia de San Millán de Oncala (Soria), Santa María del Campo (Burgos), o 16 paños del Obispado de Córdoba. También para clientes extranjeros, como cuatro paños propiedad de la República Federal de Alemania. En este momento se introduce en el área textil el bordado a máquina y la fabricación de banderas impresas; este tipo de trabajos se imponían por presiones de los gestores, que compelían a la Fundación a conducirse como una empresa mercantil, contradiciendo vivamente su naturaleza.

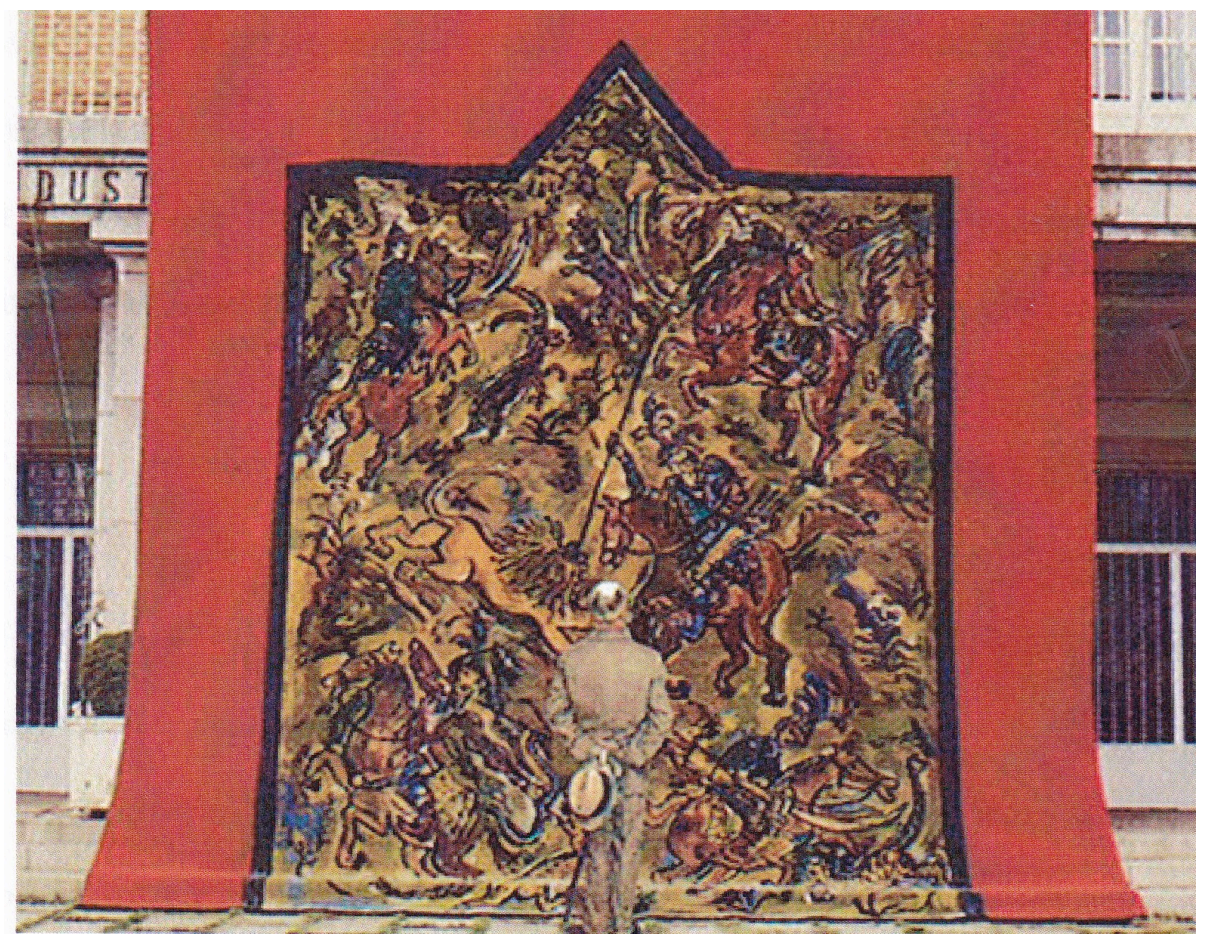

Fig. 16. Cacería persa. Alfombra de Mariscal. Archivo Sánchez-Molero. 
En los otros talleres también se intentó reunir el cultivo de la tradición con las nuevas propuestas estéticas. En la ebanistería se fabricaron algunos muebles de diseño novedoso como la mesa de taracea, modelo Sagunto, de Vaquero Turcios, elaborada en maderas de wengué, raíz de nogal y arce, o la mesa cenicero basada en un diseño de Dalí. También se reprodujeron muebles de valor histórico, como un contador de marfil y ébano al estilo holandés del XVII, que estaba expuesto en Nájera, o como los tronos de los reyes Juan Carlos y Sofía (réplica del trono de Alfonso XIII que se trasladó al palacio de la Granja) tallados, dorados y tapizados en terciopelo de seda bordado en oro, que fueron un regalo de los artesanos de la Fundación (Fig. 17). El departamento de decoración realizó obras completas en las que participaban todos los talleres. Añadamos a la relación de proyectos ya mencionados, los del palacio del Sultanato de Omán, el Hotel Beverly Wilshire en Los Ángeles, y los buques de guerra de las Armadas de México y Ecuador, entre otras. La obra más importante del taller de vidrieras es el conjunto instalado en el nuevo templo de Nuestra Señora del Buen Suceso de Madrid, edificado en 1982; también intervino el taller de ebanistería que construyó todos los elementos de madera con los restos del artesonado del antiguo edificio derribado. El taller de porcelana sufre un importante retroceso en la calidad de las pastas; el mayor patrimonio de esta sección es la colección de más de un millar de modelos diferentes.

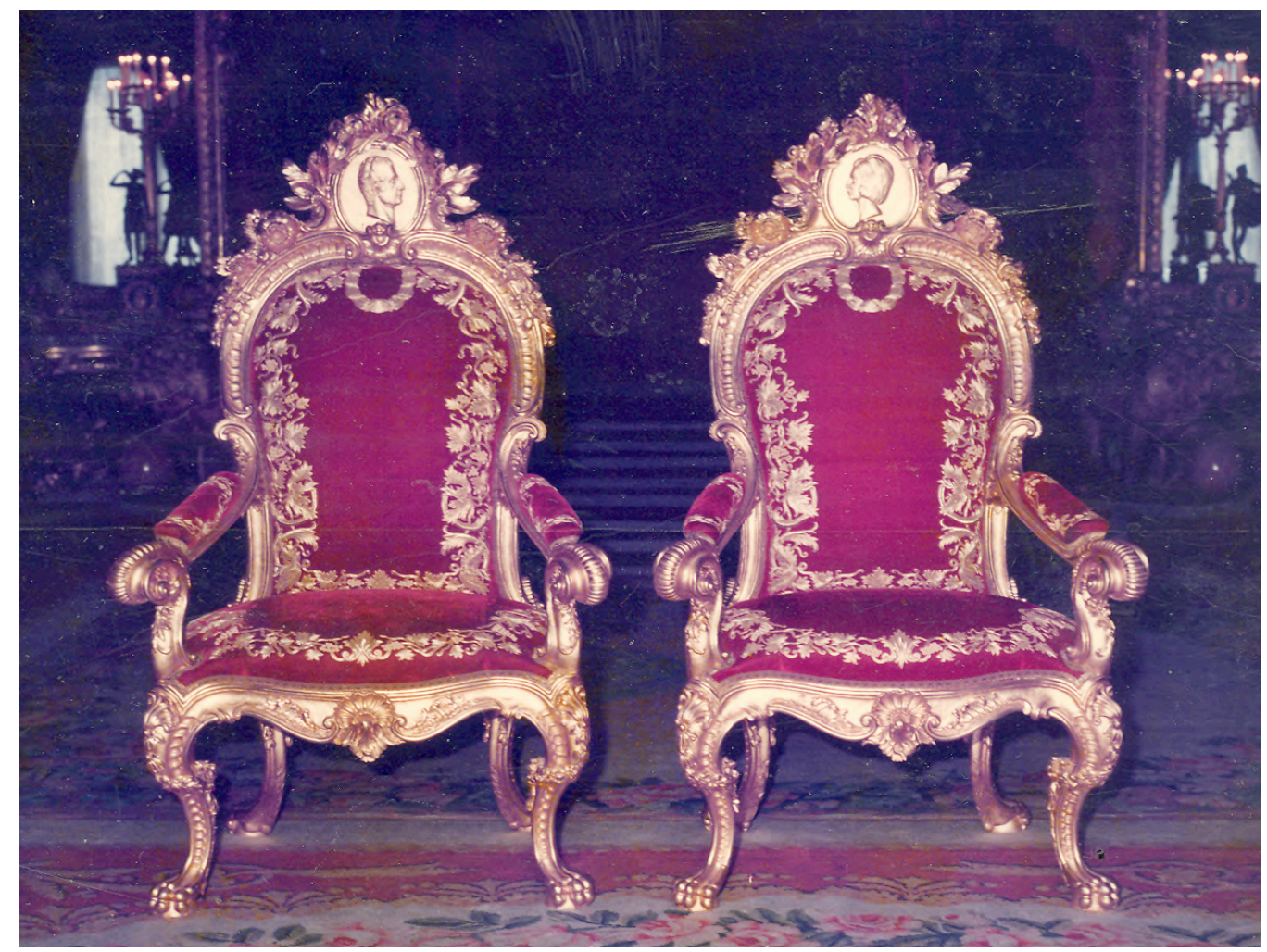

Fig. 17. Tronos de los reyes de España. Archivo Sánchez Molero.

Otra novedad que se introdujo en el área de formación durante esta etapa fue la convocatoria de los llamados Talleres de Otoño. Se celebraron cuatro entre 1985 y 1988 (I. Tapices, alfombras, tejidos, forja, dorado, talla, 
horno, decoración de porcelana; II. Tapices; III. Tapices, formas textiles; IV. Bajo lizo), pero no lograron los objetivos propuestos por la falta de continuidad y por la brevedad de los programas. Se percibe en los documentos un afán de cambio que no se sustenta en sólidos planes, lo que conduce inevitablemente al fracaso. Por otra parte, la mudanza de los métodos no satisfizo a los maestros tradicionales, pues consideraban inútiles unas enseñanzas que no estaban destinadas a arraigar en el oficio a los alumnos ${ }^{66}$.

La viabilidad económica de la Fundación había suscitado preocupaciones desde sus primeros tiempos. Por su propia naturaleza se hacía imposible subsistir sin la ayuda de subvenciones, por esa razón en 1962 se decidió la integración en el organismo de Patrimonio Nacional, para evitar la desaparición de los oficios artísticos devorados por la competencia industrial. En los años 80, en medio de una crisis económica general, se decide excluirla y buscar otras vías. Estas nuevas vías son las que se plantean en los tres planes de viabilidad que se presentan: 1983-1985, 1988-1992, 1992-1996. En todos ellos se ofrecen casi las mismas soluciones: vender terrenos, vender la sede, vender el poblado de San Francisco, reducir plantilla, fusionar el área textil con la Real Fábrica de Tapices, convertir la sección de muebles en empresa pública y unirla a Artespaña ${ }^{67}$. El resto de los talleres se cerrarían. Siguiendo la línea propuesta por estos planes, las ventas de terrenos se intensifican, de modo que a mediados de los años 80 todo el patrimonio que le resta a la Fundación es el espacio ajardinado que rodea la fábrica y algunas parcelas próximas al monte de El Pardo ${ }^{68}$. El 19 de enero de 1988 se acuerda vender la sede, con dispensa de pública subasta, al Patrimonio del Estado ${ }^{69}$, fijándose para el 31 de diciembre del mismo año el desalojo del edificio. Se decide el traslado de la fábrica a una parcela del polígono industrial de Fuencarral, propiedad de la Comunidad de Madrid, de 5.461 metros cuadrados, valorada en 36.862.000 pesetas. Para adquirirla, la Fundación ofrece en permuta varias parcelas próximas al monte de El Pardo de una extensión de 43.576'67 metros cuadrados (ocho veces más que la parcela de Fuencarral) que fueron valoradas en 22.660 .000 pesetas, por lo que la Fundación contraía además una deuda con la Comunidad de Madrid de 14.202.000 pesetas, que debería saldar en metálico. La construcción del nuevo edificio estuvo rodeada de problemas, como la desviación de los costes en un 40\% y el retraso en la entrega de dos años ${ }^{70}$. En estas circunstancias se suspende el contrato a casi toda la plantilla mediante un expediente de regulación de empleo. El único taller que se realojó parcialmente fue el de tapices, que encontró ubicación temporal en el Instituto Politécnico Virgen de la Paloma. En 1989 se produce la primera huelga general en la historia de la Fundación.

Si por una parte la Fundación pierde todo su patrimonio, por otra las modificaciones estatutarias continúan afianzando los términos de la Ley de Patrimonio. El 18 de abril de 1989 se modifica nuevamente el articulado de sus Estatutos consagrando lo que ya se apuntaba en la primera reforma de 1984: convertirla en una institución cultural de carácter privado; además sufre otro cambio en su denominación, pasando a llamarse Nueva Fundación de Gremios ${ }^{71}$. Se la dota de un nuevo Patronato que deberá nombrar a su vez un nuevo gerente. Sin embargo la gestión efectiva sigue a cargo de los órganos anteriores. Diez meses después se hacen algunos nombramientos pero los puestos quedan vacantes, los jefes de taller vuelven a hacerse cargo 
del funcionamiento diario sin ninguna cohesión ni plan interno. Se nombra nuevo Patronato en mayo de 1989 que se revela también como inoperante por inasistencia de sus titulares. Sigue el torbellino de nombramientos y ausencias, que sume a la Fundación en un caos sin solución. El 13 de septiembre de 1991 la Fundación queda inscrita en el registro correspondiente como fundación cultural privada de carácter benéfico ${ }^{72}$, lo que no impide que el Tribunal Económico Administrativo Central emita una resolución que la obliga a pagar el impuesto de lujo como si se tratara de una compañía mercantil.

El último plan de viabilidad, titulado "Estudios de escenarios de futuro. Fundación de Gremios 1992-1996" ofrecía en realidad un único escenario: la extinción. En 1992 la plantilla se reduce de nuevo. De los más de seiscientos empleos directos que había en $1945^{73}$ se pasa a noventa y dos, y en 1994 se presenta una nueva regulación para prescindir de sesenta empleados más, pero la Delegación Provincial de Trabajo de Madrid no la acepta. Se recurre nuevamente a la realización de activos, vendiendo nueve parcelas que en conjunto sumaban sesenta mil metros cuadrados, quedando reducido el patrimonio a la propia sede y a dos pequeñas parcelas que juntas sumaban ochocientos nueve metros cuadrados ${ }^{74}$. Además la nueva sede sufre una segregación en las plantas de acceso y baja, que se alquilan al Ministerio de Cultura como depósito para objetos procedentes de museos. Un último proyecto de absorción del área textil por la Real Fábrica de Tapices, la decisión de cerrar el resto de los talleres y el impago de los salarios origina la reacción de los empleados que acuden al Ministerio de Cultura solicitando una mediación que no se produce. Por fin el Ministerio autoriza la extinción el 15 de junio de 1995.

La comisión liquidadora, presidida por Jesús Viñuales hasta Septiembre de 1995 y después por Benigno Pendás, dispuso la confección de un inventario de bienes y nombró expertos para realizar la tasación. Tasamadrid S.A. valoró el inmueble, Fernando Durán los tapices, bordados, porcelanas, muebles, libros y otras piezas que se encontraban en la fábrica y en Nájera. En el proceso se dispersaron los fondos de la biblioteca, muchos bocetos y puestas en carta, la colección de matrices de Alcora, gran parte de las herramientas y el archivo documental. Se solicitaron los servicios del asesor fiscal Antonio Martínez Palomino y del despacho de abogados Héctor y Sempere, que dieron por terminado el proceso en julio de $2002^{75}$.

Este es el lugar para abordar brevemente otra de los asuntos planteados en el artículo que venimos comentando: el conflicto entre la Fundación y la Real Fábrica de Tapices. A la vista de los documentos, tanto de una como de otra institución, es posible trazar con bastante precisión la causa de este desencuentro, que no puede basarse en cuestiones meramente personales. Señalemos los jalones de ese desencuentro:

- Debemos remontarnos al tiempo de la Guerra Civil. El 21 de agosto de 1936 el Consejo de Administración del Patrimonio Nacional decide incautarse de la Real Fábrica de Tapices (el local pertenecía al Patrimonio pero todos los pertrechos de la industria eran propiedad de la familia Stuyck desde 1721). Livinio Stuyck huye de Madrid tras recibir amenazas de muerte, y se instala en San 
Sebastián donde abre una pequeña fábrica de reposteros, que suministra en ocasiones al gobierno de Franco. Al terminar la guerra Stuyck vuelve a Madrid, aplicándosele la Ley de depuración de personal de 10 de febrero de 1939 por razón de sus pasados servicios como funcionario de la República. Terminada la investigación se le admitió al servicio sin sanción ${ }^{76}$. Además hubo de someterse a los trámites administrativos dispuestos por la Comisión de Incorporación Industrial y Mercantil n. ${ }^{\circ} 1$, y a innumerables dificultades para la recuperación de los tapices robados de la sede durante la contienda. La contrariedad por sentirse injustamente tratado quedó patente en una carta a la citada Comisión ${ }^{77}$.

- En 1942 asume la dirección, tras el fallecimiento de su padre, Gabino Stuyck San Martín que vuelve a tener dificultades con el Patrimonio Nacional. Las relaciones entre la Real Fábrica y el Patrimonio seguían regulándose por las Bases de contratación firmadas en 1889, hasta que en 1951 se revisan, imponiendo al director el pago de un alquiler por la vivienda que venía disfrutando la familia en el edificio de la Fábrica. Nueva fricción que queda patente en una carta de Stuyck en la que hace mención por primera vez a la Fundación (aunque sin explicitar su nombre), quejándose de que era sostenida totalmente por el Estado. En este punto a Stuyck le cegaba el enojo, porque la Fundación, como hemos visto, era una creación de iniciativa privada y se sostenía con medios propios ${ }^{78}$. Las nuevas Bases de contratación quedarían establecidas el 25 de marzo de 1952 y firmadas el 1 de abril del mismo año ${ }^{79}$.

- En 1963 Patrimonio comunica a Stuyck la decisión de dar por terminada la vigencia del contrato de 1952 y del proyecto de derribar la sede de la Fábrica para construir un edificio de veinticinco plantas. Se pedía al director que se pusiera en contacto con el Servicio de obras, para estudiar la reinstalación de los talleres dentro del nuevo complejo ${ }^{80}$. Finalmente el proyecto no se llevó a cabo y la Real Fábrica continuó en su sede histórica.

- En 1969 se vuelve a considerar la suspensión del contrato sin que se llegue a sustanciar ningún cambio.

Las inquietudes provocadas por todas estas mudanzas, la competencia de las nuevas fábricas (no solo la Fundación, sino otras como Telas y Alfombras Españolas, la Escuela Mayor de Artesanía y las Escuelas de Artes y Oficios números 2 y 10, que además de formar nuevos profesionales podían vender sus productos), y sobre todo la incorporación de la Fundación al Patrimonio Nacional en 1962, fueron deteriorando las relaciones entre la Fábrica y el Patrimonio. Fernando Fuertes de Villavicencio, su gerente, en un intento de suavizar las tensiones, llegó a ofrecer a Stuyck la dirección de la Fundación, pero este la rechazó. Es ahora cuando algunos de los artesanos de la Real Fábrica se incorporan a la plantilla de la Fundación, atraídos por las mejoras salariales y los beneficios sociales ${ }^{81}$.

- En 1971, con motivo de los doscientos cincuenta años de la Fábrica, Stuyck emprende gestiones ante distintos organismos para 
disponer la celebración de la efeméride. El gerente de Patrimonio reconviene a Stuyck por haber saltado la cadena de mando, ya que era al Patrimonio a quien correspondía la organización. Nuevas cartas de protesta enviadas por Stuyck a Florentino Pérez Embid, director general de Bellas Artes y a Fernando Fuertes de Villavicencio $^{82}$.

- En 1975 Stuyck sigue manifestando su irritación en una entrevista periodística ${ }^{83}$, lo que nuevamente provoca una reacción de Fernando Fuertes, que en carta privada de 6 de mayo le pide una rectificación pública ${ }^{84}$.

A pesar de estas desavenencias, la Real Fábrica de Tapices vivió entre 1940 y 1975 un periodo espléndido, en el que alcanzó la mayor plantilla de su historia y un éxito comercial sin precedentes. Además sus ventas en España no se redujeron a clientes particulares, sino que muchos organismos oficiales hicieron importantes encargos. Entre sus mejores clientes mencionaremos al Ministerio de Asuntos Exteriores ${ }^{85}$, el Instituto Nacional de Industria ${ }^{86}$, el Instituto de Cultura Hispánica ${ }^{87}$.También fueron clientes los Paradores Nacionales, como el de Tordesillas, el de Bayona ${ }^{88}$ y el de Zamora ${ }^{89}$, o el Ayuntamiento de Madrid ${ }^{90}$.

- $\quad$ En 1975 muere Gabino Stuyck y le sustituye su hijo, Livinio Stuyck Pérez del Camino, que afronta un nuevo periodo de dificultades con el Patrimonio Nacional que no hace ningún encargo; su trabajo se reduce a las tareas de limpieza y restauración de la colección nacional. Patrimonio arbitra en 1988 un plan de cuatro años para repartir la carga de trabajo entre la Fundación y la Real Fábrica de Tapices, y para su debate se convoca una reunión entre todos los implicados (estamos en los momentos previos a la redacción del último plan de viabilidad de la Fundación 1988-1992), en realidad lo que se está planteando es la fusión de ambas instituciones. Se vuelve a tratar el asunto en 1994, pero no sale adelante ${ }^{91}$. Estas son circunstancias críticas para ambas fábricas, que se resolvieron de distinta manera: en el caso de la Fundación con su cierre definitivo en 1995, como hemos visto, y en de la Real Fábrica de Tapices con su transformación en una Fundación en 1996.

\section{Conclusión}

En el artículo $2^{\circ}$ de los primeros Estatutos de la Fundación (941), se establecía lo siguiente: "La Fundación tiene como fines crear fábricas y talleres donde puedan ejecutarse productos de las artes industriales de gloriosa tradición en España, como porcelanas y cerámica, muebles y bronces, cristales y lámparas, tejidos de seda y tapices, etc., dando instrucción y enseñanza gratuita en sus talleres y laboratorios a técnicos y obreros, para formar elementos que perfeccionen la industria y continúen esta tradición española, llevándola al esplendor que tuvo en siglos pasados".

Los resultados alcanzados en todos estos campos pueden deducirse de la sucinta exposición anterior, pero hay un aspecto en el que convendría dete- 
nerse algo más, porque una lectura superficial de este artículo $2^{\circ}$ puede confundir sobre un asunto de gran importancia artística. Nos estamos refiriendo al término "tradición", que se menciona dos veces en esas pocas líneas. Se corre el riesgo de asimilar tradición con rutina, copia, reiteración perezosa, en suma, arcaísmo. El hecho de que muchos de los muebles de la primera etapa se inspiraran en modelos históricos españoles, parece abonar esta opinión, sin embargo hay datos que pueden hacernos pensar que en este giro hacia el pasado hay, paradójicamente, un punto de modernidad. El marqués de Lozoya, miembro del Consejo Asesor Artístico de la Fundación, fue a su vez vicepresidente de la Hispanic Society of America, ${ }^{92}$. La labor de recuperación de nuestro patrimonio artístico que hizo esta institución en América no era solo interés arqueológico, sino admiración por la belleza de los muebles y los estilos decorativos del pasado español. Es fácil pensar que el marqués de Lozoya fuera uno de los impulsores de esta línea de trabajo en el taller de ebanistería de la Fundación, haciendo revivir un estilo que tanto entusiasmo venía despertando desde años atrás en Norteamérica.

Pero no hay que perder de vista la otra forma de entender la tradición, la genuina, que nos remite a su etimología latina (tradere, transmitir o entregar). Así es cómo la interpretaban los miembros del Consejo de Administración de la Fundación durante la primera etapa. En 1942 manifiestan expresamente el deseo de construir algo nuevo sobre el legado del pasado con estas palabras referidas al taller de porcelana: "Esta instalación puede servirnos para adquirir cierta práctica y permitirnos aprender a hacer porcelana. La experiencia así adquirida nos bastará para resolver las dudas que actualmente tenemos sobre lo que debe ser una Fábrica de porcelana concebida con un criterio de la época actual. Hay en esta industria cerámica un amor a la tradición que no puede armonizarse con un sentido industrial moderno, ni con el progreso de las bellas artes; si nos quisiéramos encerrar en el gusto del pasado y seguir reproduciendo indefinidamente los modelos de la época de Carlos III y Carlos IV caeríamos en un amaneramiento inadmisible" ${ }^{93}$. En cuanto a las obras del taller de tapicería que mencionamos en su momento, Los músicos de Capuleto y La toma de Granada de Carlos Sáez de Tejada son en sí mismos una declaración de principios.

Esta era la orientación que también se venía sosteniendo en la Obra Sindical "Artesanía”, cuando en 1943 se convoca el I Concurso Nacional de Artesanía. En el acta de 30 de noviembre el jurado hace constar que existía "una reiteración de técnicas y conceptos artesanos ya conocidos, si bien no se le oculta que dichas actividades pueden ser totalmente renovadas en cuanto a estilo, una vez que a esto artesanos se les facilite asesoramiento artístico adecuado"94; y con mayor claridad en la Revista de las Artes y los Oficios, donde abogaba por seguir el camino marcado Francia en materia de tapicería ${ }^{95}$.

Esta misma decisión de renovar la tradición se evidencia en un tapiz tejido en la Escuela Mayor de Artesanía (último grado del plan de estudios ${ }^{96}$ impulsado por esta Obra Sindical. Fig. 18) sobre otra obra de Vázquez Díaz, basada en los frescos de La Rábida ${ }^{97}$. Y para ofrecer un último ejemplo, los propios locales del I Mercado de Artesanía, de la calle Floridablanca n. ${ }^{\circ}$ 1, son testimonio de esta modernidad; en su decoración interior intervinieron Luis María Feduchi, Joaquín Vaquero Palacios, Serny, Carlos Tauler, y Manuel Eguía, coordinados por Gerardo Salvador Merino y Enrique Caruncho. 


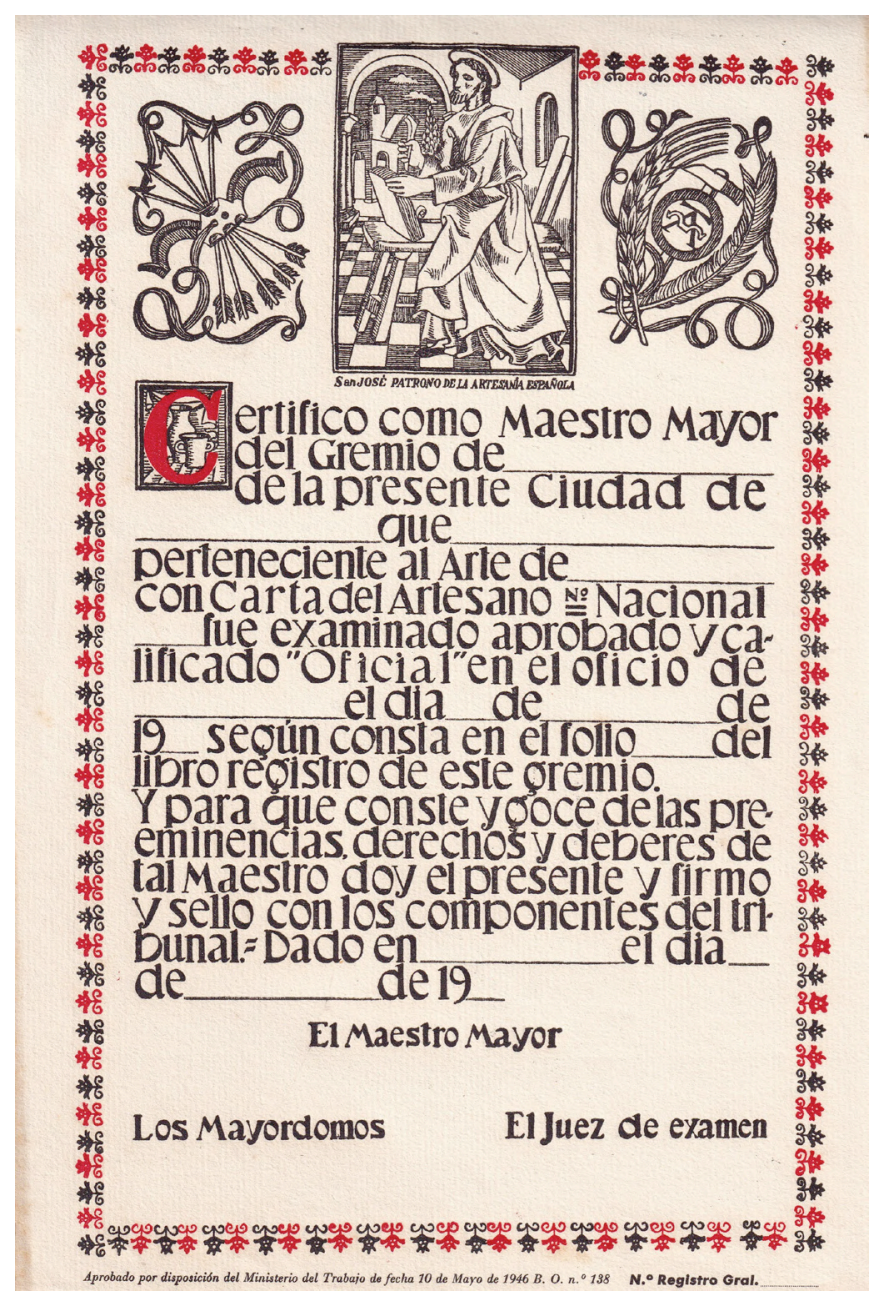

Fig. 18. Certificado expedido por el Maestro Mayor del Gremio. Archivo de Laura de la Calle Vian.

Este mismo afán de renovación se desarrolla en la Escuela de Artes y Oficios $\mathrm{n}^{\circ}$ 2, cuando en su taller de tapices se teje Las amazonas sobre un modelo de Vázquez Díaz ${ }^{98}$, o Las Navas de Tolosa de Ramón Stolz Viciano ${ }^{99}$.

La influencia de la Obra Sindical "Artesanía" se va debilitando progresivamente a partir de 1957, fecha en que promueve la celebración un importante Congreso ${ }^{100}$, en el que se hacen propuestas tan novedosas como la promulgación de un Estatuto Artesano, la creación de una Mutualidad de previsión social del artesanado, el establecimiento de una Caja Nacional de crédito artesano y de un régimen fiscal preferente. Todas estas iniciativas se vieron paralizadas hasta que se incorporaron a los debates del I Plan de Desarrollo (1964-1967) ${ }^{101}$.

En el segundo periodo de la Fundación, entre 1962 y 1975, sobrevive ese mismo impulso cuando José Luis Miranda y Galo Brull renuevan los modelos del taller de reposteros, por ejemplo. Incluso en la tercera etapa, en plena crisis, los talleres manifiestan su deseo de seguir innovando. A este propósito responden los muebles, tapices y alfombras de Vaquero Turcios, la alfombra diseñada por Mariscal, o la fabricación de la mesa cenicero inspirada en una obra de Dalí. Para progresar en idéntica dirección se convocaron los Talleres de Otoño, aunque no llegaran a lograr su objetivo. 
Debemos concluir, a la vista de las obras, que la Fundación entendió la tradición como un constante fluir que, apoyándose en los logros del pasado, se proyectaba hacia el futuro.

\section{NOTAS}

${ }^{1}$ Ana María Fernández García, "La Fundación Generalísimo Franco o Fundación de Gremios. Mueble y artesanía en España (1941-1995)," Res Mobilis. Revista internacional de investigación en mobiliario y objetos decorativos, 10, n. ${ }^{\circ} 13$ (febrero 2021): 245. https.//doi.org/10.17811/ rm.10.12.2021.

${ }^{2}$ Con este nombre abreviado aparece siempre en todos los documentos internos y, por tanto, así nos referiremos a ella en adelante.

${ }^{3}$ Laura de la Calle Vian, La Edad de Plata de la tapicería española (Madrid: Fundación Universitaria Española, 2013), 249-322, 440-444, 399-419, 484-491.

4 - Estatutos de la Fundación Generalísimo Franco-Industrias Artísticas Agrupadas, de 7 de febrero de 1941. Notaría de Rafael Núñez-Lagos.

- Escritura de modificación de los Estatutos de la Fundación Generalísimo Franco-Industrias Artísticas Agrupadas, de 4 de diciembre de 1962, n. ${ }^{\circ}$ 2.210. Notaría de Rafael Núñez-Lagos.

- Escritura de modificación de los Estatutos de la Fundación Generalísimo Franco-Industrias Artísticas Agrupadas, de 22 de mayo de 1984, n. ${ }^{\circ}$ 1085. Notaría de Antonio Rodríguez Adrados.

- Escritura de modificación de los Estatutos de la Fundación Generalísimo Franco-Industrias Artísticas Agrupadas, de 28 de noviembre de 1984, n. ${ }^{\circ}$ 2.473. Notaría de Antonio Rodríguez Adrados. Documento unido: certificación de los acuerdos del Consejo de Administración del Patrimonio Nacional adoptados en su reunión de 24 de septiembre de 1984, firmada por Amando de las Alas Pumariño y Cima.

- Escritura de modificación de los Estatutos de la Fundación de Gremios-Industrias Artísticas Agrupadas, de 18 de abril de 1989, n. ${ }^{\circ}$ 759. Notaría de Antonio Rodríguez Adrados. Documento unido: certificación del acuerdo adoptado por el Consejo de Administración del Patrimonio Nacional en su reunión de 25 de octubre de 1988, firmada por Fernando Díaz Moreno.

5 Asisten a esta primera reunión del Consejo: Presidente, Manuel Escrivá de Romaní, conde de Casal. Director gerente, Bernardo Suárez Crosa. Secretario general, José Antonio Botella Domínguez, marqués de Colomina. Vocales: Juan Botella Valor, en representación del Obispo de Madrid-Alcalá. Epifanio Ridruejo Botija. Pío Suárez Inclán. Eloy Domínguez Veiga. Pedro Masaveu Masaveu. Faltó por razones de salud, Martín González del Valle, marqués de Vega de Anzo. (Archivo Ministerio de Cultura. Fundación de Gremios. Libro de actas, pp. 3-15). El conde de Casal presenta su dimisión en Mayo de 1941 (ibidem, p. 32), pero no cesó como Presidente del Consejo de Administración hasta el 18 de diciembre de 1941. Con la misma fecha fue nombrado para el cargo Pedro Masaveu Masaveu (ibidem p.55) que permaneció en el puesto hasta el 28 de noviembre de 1962. En ausencia del conde de Casal y hasta la toma de posesión de Pedro Masaveu (entre abril y diciembre de 1941) Suárez Crosa asumió la responsabilidad.

${ }^{6}$ Para más datos sobre la trayectoria profesional de Bernardo Suárez Crosa y Juan Eguiagaray Senárega, anterior y posterior a su integración en la Fundación, Laura de la Calle Vian, op. cit. pp. 323 y ss.

${ }^{7}$ Archivo General de Palacio. Secc. Adm. Ca 2289. Exp. 5.

${ }^{8}$ Archivo de la Villa de Madrid. Exp. Sig. 6-386-4.

${ }^{9}$ Acta del Consejo de Administración de la Fundación de 28 de agosto de 1942, y Acta de 29 de mayo de 1943 (Archivo Ministerio de Cultura. Fundación de Gremios. Libro de actas, p. 86 y 168 respectivamente). 
${ }^{10}$ La licencia de apertura para la instalación de un taller de ebanistería y restauración de muebles antiguos fue solicitada por Juan Eguiagaray al Ayuntamiento de Alcalá de Henares el día 1 de junio de 1941. La autorización le fue concedida el 23 del mismo mes y año. (Archivo Municipal de Alcalá de Henares, Leg. 1363/1).Estos locales alojaron el primer taller de ebanistería de la Fundación. Poco después, ante el aumento de pedidos y la estrechez del local, se decide el traslado al antiguo convento del Carmen Calzado, que en aquellas fechas estaba cerrado.

${ }^{11}$ Se adopta esta grafía por ser la más utilizada en los documentos y por ser la forma en la que aparece siempre en los folletos comerciales de la Fundación. También se presenta, aunque con menos frecuencia, como Fuente la Reina o Fuentelarreina.

${ }^{12}$ El restaurante fue construido sobre planos de Luis Gutiérrez Soto y decorado con pinturas de Hipólito Hidalgo de Caviedes.

${ }^{13}$ Actas del Consejo de Administración de la Fundación de 23 de diciembre de 1941, 26 de febrero de 1942 y 6 de marzo de 1942. Archivo del Ministerio de Cultura. Fundación de Gremios. Libro de actas, pp. 53, 60-62, y 66-67 respectivamente.

${ }^{14}$ Archivo General de Palacio. Secc.Adm. C ${ }^{a}$ 3081, Exp. 11.

${ }^{15}$ Acta del Consejo de Administración de la Fundación de 29 de mayo de 1943. Archivo del Ministerio de Cultura. Fundación de Gremios. Libro de actas, p. 169.

${ }^{16}$ Escrito firmado por Tomás de Allende, presidente de la Sociedad de Tiro de Pichón. Archivo General de Palacio. Secc. Adm. C C $^{\text {3588. Exp.49. }}$

${ }_{17}$ Escrito de Bernardo Suárez Crosa de 20 de enero de 1942 dirigido a Adolfo Vara de Rey, y Acta de 17 de marzo de 1942 firmada por Adolfo Vara de Rey y Herrán, consejero delegado gerente del Patrimonio Nacional, y Bernardo Suárez Crosa, gerente de la Fundación, en la que se acuerda ceder a la Fundación la parcela de Fuentelarreyna. Unido hay un plano de este paraje y de los terrenos del Cuartel de Somontes, donde se señala el solar ocupado por la Sociedad de Tiro de Pichón y la parcela cedida a la Fundación (Archivo General de Palacio.

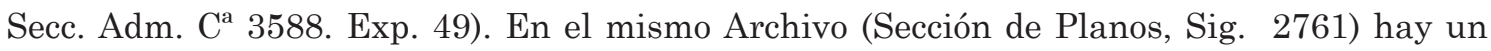
plano completo del Monte de El Pardo, levantado en 1955 por el arquitecto Diego Méndez, en el que se señalan en la zona sur todas las parcelas enajenadas a distintos compradores.

${ }^{18}$ Archivo General de Palacio. Secc.Adm. C ${ }^{a}$ 3081. Exp. 11.

${ }^{19}$ Ley de 7 de marzo de 1940 restableciendo a la plenitud de su tradicional significación los bienes constitutivos del antiguo Patrimonio de la Corona. Boletín Oficial del Estado de 8 de marzo de 1940, pp. 1672-1674. https://www.boe.es/datos/pdfs/BOE//1940/068/A01672-01674.pdf.

En su artículo $5^{\mathrm{a}}$ la Ley disponía: "Los bienes que integran el Patrimonio Nacional, cuya propiedad corresponde al Estado, son inalienables e imprescriptibles, y no podrán sujetarse a ningún gravamen real ni a ninguna otra responsabilidad. No obstante, podrán enajenarse, previa autorización por Decreto acordado en Consejo de Ministros y a condición de ingresar su importe en el Tesoro, o ser dedicado al saneamiento y mejora de los bienes constitutivos del Patrimonio, aquellos bienes inmuebles que carezcan de valor artístico o histórico y no sean aptos, por su naturaleza y la cuantía de sus productos, para ser mantenidos en el Patrimonio", p. 1672.

${ }^{20}$ Presidencia del Gobierno. Decreto de 13 de diciembre de 1945, por el que se autoriza al Consejo de Administración del Patrimonio Nacional para enajenar, previa su segregación del Monte de El Pardo, tres parcelas en los Cuarteles de El Águila y El Goloso, Zarzuela y Portillo y Somontes. Boletín Oficial del Estado n. ${ }^{\circ} 351$, de 17 de diciembre de 1945, pp. 3539-3540. https://www.boe.es/gazeta/dias/1945/12/17/pdfs/BOE-1945-351.pdf.

Las palabras referidas a la parcela solicitada son las siguientes: "El Consejo de Administración del Patrimonio Nacional solicita la necesaria autorización que previene la Ley de siete de marzo de mil novecientos cuarenta para proceder a la enajenación de diversas parcelas del 
Monte de El Pardo y sitas en los límites del mismo. Segregación fundamentada en la división del Monte que ha originado las obras del Ferrocarril Madrid-Burgos, por una parte; en la rectificación que se hizo de la nueva tapia a fin de dar posibilidades de expansión al pueblo de El Plantío, en segundo término; y finalmente, en cuanto a la parcela de Somontes estabilizar la situación jurídica de la Institución concesionaria de aquélla. Quedando el resto del Monte formando un todo unitario, perfectamente delimitado y cercado". En su virtud, el Patrimonio Nacional exigió a la Fundación que reconstruyera los 1.145 metros lineales de tapia desde el límite norte de la parcela, rodeándola por el oeste, hasta unirla con el resto de la valla, segregando así el terreno vendido. Archivo General de Palacio. Secc. Adm. C ${ }^{\text {a } 3081 . ~ E x p . ~} 11$.

${ }^{21}$ Escritura de compraventa n. ${ }^{0} 1283$, de la Notaría de Rafael Núñez-Lagos, fechada el 7 de octubre de 1947 Archivo General de Palacio. Secc. Adm. Ca 3081. Exp. 62.

${ }^{22}$ Orden del Ministerio de Justicia de 7 de octubre de 1938 por la que se crea el Patronato Central para la Redención de Penas por el Trabajo. Boletín Oficial del Estado n. ${ }^{\circ}$ 103, de 11 de octubre, pp. 1742-1744. https://drive.google.com/file/d/1B1o3d6x2whxFQkNv6rSRwYfQm6I2oW4w/view.

Un estudio exhaustivo de todas las disposiciones legales relacionadas con la materia en: Francisco Bueno Arús, "La redención de penas por el trabajo en el ordenamiento jurídico español". Tesis para optar al grado de doctor, Madrid: Universidad Complutense. Facultad de Derecho, Universidad Complutense, 1973). https://eprints.ucm.es/id/eprint/54380/1/5327076589.pdf

${ }^{23}$ Acta del Consejo de Administración de la Fundación de 24 de junio de 1941. Archivo del Ministerio de Cultura. Fundación de Gremios. Libro de actas, p. 34.

${ }^{24}$ Medidas: $230 \mathrm{~cm}$. de ancho por $139 \mathrm{~cm}$. de alto. Colección particular. Ver: Laura de la Calle Vian, op. cit., 489.

${ }^{25}$ Medidas: $640 \mathrm{~cm}$. de ancho por $362 \mathrm{~cm}$. de alto. Boceto n. ${ }^{\circ} 260$ del catálogo de la Fundación. Una pequeña fotografía en blanco y negro se conserva en el Archivo del Museo de Artes Decorativas de Madrid. El cartón se encuentra en la Casa de la Moneda, entidad para la que se realizó la obra. El tapiz desapareció después de haber participado en una exposición a finales de los años 70, y continúa en ignorado paradero (Ibidem).

${ }^{26}$ Medidas: $241 \mathrm{~cm}$. de ancho por $196 \mathrm{~cm}$. de alto. El repostero pertenece a la colección de la Sociedad Española de Participaciones Industriales. El mismo boceto fue tejido como tapiz en las siguientes medidas: $570 \mathrm{~cm}$. de ancho por $200 \mathrm{~cm}$. de alto; esta última obra está en paradero desconocido.

${ }^{27}$ Archivo del Ministerio de Cultura. Fundación de Gremios. Libro de actas, pp. 48-49.

${ }^{28}$ Archivo del Ministerio de Cultura. Fundación de Gremios. Libro de actas, pp.14, 41,42, 74.

${ }^{29}$ En la temprana fecha de 1941 la Fundación, por medio de Botella Valor, mantuvo conversaciones con el secretario general del Consejo Superior de Investigaciones Científicas, José María Albareda, para la creación de un Instituto de Investigaciones Cerámicas titulado "Sureda”, que dependería del Patronato Juan de la Cierva. El nuevo Instituto se dedicaría al estudio de los caolines españoles y radicaría en los laboratorios de la propia Fundación. Este Instituto no llegó a crearse a pesar de la buena acogida que tuvo el proyecto. (Acta del Consejo de Administración de la Fundación de 26 de noviembre de 1941 y Acta de 30 de abril de 1942 Archivo del Ministerio de Cultura. Fundación de Gremios. Libro de actas, pp. 48-49, y pp. 72 73 respectivamente). La Fundación también participó en el Tercer Congreso Internacional de Reactividad de los Sólidos, que se celebró en Madrid en 1956.

${ }^{30}$ Acta del Consejo de Administración de la Fundación de 29 de abril de 1942. Archivo del Ministerio de Cultura. Fundación de Gremios. Libro de actas, p. 70.

${ }^{31}$ Se le ofrece contrato por un año, prorrogable indefinidamente por acuerdo tácito entre las partes, y un salario de 3.000 pesetas mensuales; a su ayudante, Mr. Pietri, se le fija un salario mensual de 1.000 pesetas. En octubre de 1942 se alcanza un acuerdo final con Molho, quien 
además ofrece traer a España toda su colección de modelos para usarla en la enseñanza de los aprendices españoles que, provenientes de la Escuela de Artes y Oficios, formaron pronto un buen equipo. Acta del Consejo de Administración de la Fundación de 29 de abril de 1942, de 28 de mayo de 1942 y de 17 de octubre de 1942. Archivo del Ministerio de Cultura. Fundación de Gremios. Libro de actas, pp. 70, 74 y 93 respectivamente.

${ }^{32}$ La Obra Sindical "Artesanía" había hecho algunas gestiones previas al respecto. El proyecto que estaban considerando era el siguiente: primero, comprar las matrices de la fábrica y, después, adaptar los locales del antiguo convento de San Francisco de Alcora para establecer allí un Taller-Escuela de cerámica. Finalmente, como hemos visto, pasaron a poder de la Fundación.

${ }^{33}$ Algunas de estas obras aparecen en el libro que se editó al finalizar la exposición, donde se narran los preparativos y la crónica del viaje día por día, ilustrado todo con numerosas fotografías. El viaje del Ciudad de Toledo. Exposición flotante española 1956 (Madrid: Ministerio de Comercio, 1957):18, 94 y 119.

${ }^{34} \mathrm{El}$ repostero reproduce con exactitud una vista panorámica de la ciudad. Para la realización del dibujo, Manuel Mingote, dibujante de la Fundación, trabajó con varias fotografías del paraje tomadas ex profeso; para la confección los artesanos utilizaron siete mil quinientas piezas de distintos paños, fabricados en la sección de tejidos de la Fundación. Este repostero fue regalado posteriormente al sultán Mohamed V, que había visitado la Exposición Flotante durante su escala en Casablanca el día 13 de diciembre de 1956.

${ }^{35}$ Esta espléndida réplica pasó a una colección privada poco antes de que la Fundación fuera cerrada; con ella se pagó la deuda contraída con uno de sus proveedores. Este sistema de pago se utilizó para saldar otros débitos durante la última etapa de la institución.

${ }^{36}$ Artículo 17. "Los productos líquidos de cada ejercicio, deducidas todas las cargas, gastos y amortizaciones, constituirán los beneficios de la Institución, que habrán de ser aplicados en la forma siguiente: $1 .{ }^{\circ}$ Cinco por ciento para fondos de reserva. $2 .^{\circ}$ Diez por ciento para remuneración a los miembros del Consejo de Administración, vocales del Consejo Asesor Artístico y personal directivo, según propuesta formulada por el Consejo de Administración y aprobada por el fundador. $3 .^{\circ}$ El resto de los beneficios se aplicará al perfeccionamiento y ampliación de las industrias que necesiten ser perfeccionadas o creadas y a propulsar y premiar al personal técnico y obrero, así como a instituir obras sociales, previo acuerdo del pleno del Patronato y aprobación del fundador.".

${ }^{37}$ A partir de 1946 se abrieron talleres de alfombras en Boñar, Illora, Albalate de Zorita, Almería, Chamartín de la Rosa, Chinchón, Hervás, Villadiego, Los Yébenes, Herrera de Pisuerga, Almena, Aranjuez, Burgos, Canillas, Cubas de la Sagra, Cuevas de Almanzora, Grado y Herencia con un total de 200 telares instalados. Así mismo se ayudó a la instalación de varios talleres familiares de cerámica en el vecino pueblo de Peña Grande.

${ }^{38}$ Acta 1 septiembre 1942. Archivo del Ministerio de Cultura. Fundación de Gremios. Libro de actas, p. 90. Tres meses antes, en junio, se habían barajado varias posibilidades para la adquisición de los terrenos: 1. Compra por parte del Ayuntamiento y cesión de los solares a la Fundación al precio de compra, resarciéndose de los gastos con la venta del terreno sobrante. 2. Expropiación, cargando con los gastos la Fundación. 3. Compra total a cargo de la Fundación y venta de lo sobrante. En marzo de 1943 continúan las gestiones encaminadas a adquirir el terreno, esta vez se propone al Ministerio de Trabajo que éste compre entre cien y ciento cincuenta hectáreas de terreno en las proximidades de la fábrica y ceda a la Fundación una pequeña parte a cambio de las obras de saneamiento, comunicaciones y construcción de las casas, para después en plazo acordado ir reintegrando el capital invertido. Ninguna de estas opciones se llevó a cabo.

${ }^{39}$ Actas del Consejo de Administración 29 de abril de 1944 y de 1 de mayo de 1944. Archivo del Ministerio de Cultura. Fundación de Gremios. Libro de actas, pp. 198 y 199. 
${ }^{40}$ Acta del Consejo de Administración de 26 de febrero de 1944. Archivo del Ministerio de Cultura. Fundación de Gremios. Libro de actas, p. 191.

${ }^{41}$ Informe de Luis Jordana de Pozas. Acta del Consejo de Administración de 25 de marzo de 1941. Archivo del Ministerio de Cultura. Fundación de Gremios. Libro de actas, p.20 y ss. En el informe Jordana sugiere distintas vías de financiación y propone convertir el poblado en un municipio independiente o entidad local menor, cuyo desarrollo debía recaer en los órganos correspondientes de la Administración. Sin embargo, y sin despreciar las contribuciones puntuales de algunos organismos oficiales para saneamiento o comunicaciones (que beneficiaban también a los municipios cercanos y revalorizaban los terrenos circundantes) no se tomó en consideración esta propuesta y el poblado se construyó a expensas de la Fundación.

${ }^{42}$ El Consejo de Administración en reunión de 17 de marzo de 1941 designa a Epifanio Ridruejo Botija como delegado especial para que verifique la operación. Archivo del Ministerio de Cultura. Fundación de Gremios. Libro de actas, p. 18.

${ }^{43}$ Archivo del Ministerio de Cultura. Fundación de Gremios. Libro de actas, p. 177.

${ }^{44}$ Acta del Consejo de Administración de 28 de noviembre de 1962. Archivo del Ministerio de Cultura. Fundación de Gremios. Libro de actas, p. 680.

${ }^{45}$ El 26 de junio de 1946, ante la enorme carga de trabajo que pesaba sobre Suárez Crosa, se acuerda desdoblar el cargo, nombrando al antedicho director general de la Fundación y gerente a Andrés Ruiz Pla. Archivo del Ministerio de Cultura. Fundación de Gremios. Libro de actas, p. 302.

Merece señalarse los siguientes datos que pueden servir para completar el balance de los servicios prestados por Suárez Crosa. Este primer gerente trabajó de forma gratuita durante las semanas previas a la creación de la Fundación. Cinco meses después de la puesta en marcha seguía sin recibir ningún sueldo. En la reunión del Consejo de Administración de 26 de junio de 1941, tras deliberaciones previas (a las que no asistió Suárez Crosa para no incomodar a los Consejeros con su presencia y coartar su libertad de expresión), se le asignó un salario anual de 48.000 pesetas, que el propio interesado en reunión posterior, después de manifestar su agradecimiento, rebajó a 24.000 pesetas, añadiendo que hasta que la fábrica no cobrara vuelo suficiente no aceptaría pago alguno. Idéntico gesto hizo el secretario General, Antonio Botella, con su asignación. En junio del año 42 no habían cobrado todavía ni una mensualidad ninguno de los dos. (Archivo del Ministerio de Cultura. Fundación de Gremios. Libro de actas, pp. 36-37 y 84). Al ser nombrado director general el 26 de junio de 1946 el Consejo acuerda concederle un considerable aumento de sueldo. La respuesta de Suárez Crosa a este incremento fue que se consideraba suficientemente retribuido y que no necesitaba nuevos estímulos económicos. (Libro de actas, p 302). Recordemos, para establecer una comparación útil, que en 1942 se había fijado al Sr. Molho, Jefe del taller de porcelana, un sueldo anual de 36.000 pesetas.

${ }^{46}$ En los primeros años, durante la gerencia de Suárez Crosa, como ya hemos mencionado, se emprendió una política de compras de terrenos, la mayoría pequeñas huertas en los municipios de Peña Grande y Fuencarral, con el fin de dotar a la Fundación de espacio suficiente para levantar las fábricas de porcelana y cristal, previstas en el primer proyecto, así como de proporcionarle una garantía económica. En 1947 la Fundación era propietaria de 1.316.634'90 m2. El 7 de diciembre de 1947 la Fundación adquiere 230.000 metros cuadrados de la parcela del Cuartel de Somontes. Los trabajos de urbanización emprendidos y la mejora de los transportes, revalorizaron los terrenos circundantes, de modo que las adquisiciones debieron cesar por no estar ya al alcance de la institución. En 1962, tras realizarse algunas ventas desde la entrada en el Consejo de Administración de Luis Auguet Durán, le quedan a la Fundación 1.059.134'90 m2. "Análisis de inmovilizado. Terrenos", Archivo del TrabajoFundación $1^{\circ}$ de Mayo. Fondo documental Fundación de Gremios. Sig. 1/9. 
${ }^{47}$ Los balances de 1958 y 1959 tienen unido un escrito sin firmar, que parece un informe independiente redactado en 1961, es decir, poco antes de que el fundador decidiera el cambio de naturaleza jurídica de la Fundación. El informe pone de manifiesto que la nueva gerencia de Auguet no había resuelto el problema de caja. Se detallan los grandes gastos hechos por él y por su ayudante en uno de los tres viajes a América que hicieron, sin que el resultado fuera de utilidad. Hay desorden en el taller de tapices; los tejedores reclaman a la dirección el aumento de categoría que les correspondía y han debido recurrir a la Magistratura de Trabajo. Nájera ha bajado tanto las ventas que no cubre los gastos. El tono del escrito es duro. Archivo de la Fundación Nacional Francisco Franco. Sig. 4210.

${ }^{48}$ Escritura de modificación de los Estatutos de la Fundación Generalísimo Franco-Industrias Artísticas Agrupadas, de 4 de diciembre de 1962, número 2.210 de la notaría de Rafael Núñez-Lagos. En su artículo 5. ${ }^{\circ}$ se disponía: "El patronato de la Fundación corresponde al Jefe del Estado, y al igual que los Patronatos a que se refiere la Ley de 7 de marzo de 1940 quedará integrado en el Patrimonio Nacional".

${ }^{49}$ En el diseño de los cartones participaron Ángel del Campo Francés, Gabino Stuyck y Faustino Álvarez. Archivo Histórico de la Real Fábrica de Tapices. Sig. 96/10.5. Ramón Faraldo, "Participación de la Real Fábrica en el concurso de tapices para el Valle de los Caídos", Arte Hogar. El Globo, n. 157 (enero de 1958): 5. Conversación de la autora con Ángel del Campo Francés el día 29 de junio de 2005.

${ }^{50}$ Los bocetos, que no llegaron a tejerse, fueron adquiridos por un coleccionista norteamericano en 1966. Ver: Laura Arias Serrano, Juan Antonio Morales. De la vanguardia al retrato de sociedad. (Valladolid: Excelentísima Diputación, 2005), 203.

${ }^{51}$ Es necesario aclarar algunos detalles del artículo que estamos glosando en relación con esta serie del Apocalipsis. La edición príncipe de mediados del siglo XVI, sobre cartones de Van Orley (inspirado a su vez por grabados de Durero) fue tejida, primero, por Jan Gheteels y llegó al puerto de Laredo el 8 de septiembre de 1559; en la operación de desembarco, a causa de un temporal, perecieron seis de los ocho paños del conjunto, por lo que Felipe II dispuso que Guillermo Pannemacker retejiera los perdidos. La serie completa llegó a España por tierra en 1562.Ver: Paulina Junquera de Vega y Concha Herrero Carretero, Catálogo de tapices del Patrimonio Nacional. Siglo XVI, (Madrid: Patrimonio Nacional, 1986), 54-62. La edición tejida en la Fundación se realizó entre noviembre de 1964 y diciembre de 1975, es la única réplica que se ha hecho hasta la fecha de la serie flamenca, y es tan original como la primera de Gheteels o la de Pannemacker. Para comprender esta afirmación bastará con recurrir a una sencilla comparación musical: la interpretación de una partitura es siempre original, sea cual sea el tiempo de su ejecución. Las réplicas han sido siempre práctica habitual de todos los talleres de tapices cuando algún diseño tenía gran aceptación. ¿Alguien podría decir si la serie diseñada por Rafael de Urbino Los Hechos de los Apóstoles perteneciente al Patrimonio Nacional es menos original que la serie de la capilla Sixtina del Vaticano? El Apocalipsis de San Juan de la Basílica madrileña es una interpretación magnífica que resiste cualquier comparación con la edición príncipe. Acabada la serie en 1975, Patrimonio Nacional editó un libro titulado Los tapices del Apocalipsis de San Juan. Reproducciones realizadas por la Fundación Generalísimo Franco para el Valle de los Caídos. El libro se terminó de imprimir el 19 de marzo de 1976. Se incluían dieciséis fotografías, ocho de la serie del siglo XVI y otras ocho de esta segunda edición, con el fin de que se pudiera hacer la comparación entre las dos obras. Se hicieron tan solo veinticinco ejemplares del libro, dos de los cuales están al alcance de los investigadores: uno en la biblioteca del Palacio Real de Madrid, y otro en la biblioteca de la Fundación Nacional Francisco Franco. Estudio detallado de la réplica en Laura de la Calle Vian, op. cit., 282-291.

${ }^{52}$ Ordenanza Laboral para la Fundación Generalísimo Franco-Industrias Artísticas Agrupadas. Orden del Ministerio de Trabajo de 15 de junio de 1969. Boletín Oficial del Estado n. ${ }^{\circ}$ 
186 de 5 de agosto de 1969. Reglamento de Régimen Interior de la Fundación Generalísimo Franco-Industrias Artísticas Agrupadas. Resolución de la Dirección General de Trabajo de 14 de octubre de 1969.

${ }^{53}$ Según lo dispuesto en el artículo octavo de la Ley de 7 de marzo de 1940, restableciendo a la plenitud de su tradicional significación los bienes constitutivos del antiguo Patrimonio de la Corona, que dice así: "Corresponderá al Jefe del Estado el ejercicio de los derechos correspondientes a los Patronatos que forman parte del Patrimonio Nacional.”. Boletín Oficial del Estado de 8 de marzo de 1940, p. 1.672.

${ }^{54} \mathrm{Su}$ fundadora y presidenta fue María Rosa Suárez-Inclán Ducassi, entonces directora general del Patrimonio Histórico y Cultural de la Comunidad Autónoma de Castilla y León.

${ }^{55}$ La prensa publicó este informe: "Adelpha propone soluciones a la crisis de la Real Fábrica de Tapices”, El País, 28 de noviembre de 1979. https:/elpais.com/diario/1979/11/28/cultura/312591605_850215.html

${ }^{56}$ Boletín Oficial de las Cortes Generales, 22 diciembre de 1981.

${ }^{57}$ Boletín Oficial de las Cortes Generales, Congreso de los Diputados, de 20 de marzo de 1981. B

${ }^{58}$ Diario de sesiones del Congreso de los Diputados n. ${ }^{\circ} 48$. Comisión de Presupuestos. Acta taquigráfica de la sesión celebrada el lunes 26 de octubre de 1981, pp. 2.151 y 2.152.

${ }^{59}$ Archivo del Trabajo. Fundación $1^{\circ}$ de Mayo. Fondo documental Fundación de Gremios. Sig. $12 / 29$.

${ }^{60}$ Boletín Oficial del Estado n. ${ }^{\circ}$ 148, de 22 de junio de 1982, pp. 16.948-16.950. https://www. boe.es/eli/es/1/1982/06/16/23.

"Artículo quinto. Forman parte del Patrimonio Nacional los derechos de patronato o de gobierno y administración sobre las siguientes Fundaciones, denominadas Reales Patronatos: Uno. La Iglesia y Convento de la Encarnación. Dos. La Iglesia y Hospital del Buen Suceso. Tres. El Convento de las Descalzas Reales. Cuatro. La Real Basílica de Atocha. Cinco. La Iglesia y Colegio de Santa Isabel. Seis. La Iglesia y Colegio de Loreto, en Madrid, donde también radican los citados en los apartados precedentes. Siete. El Monasterio de San Lorenzo de El Escorial, sito en dicha localidad. Ocho. El Monasterio de Las Huelgas, en Burgos. Nueve. El Hospital del Rey, sito en dicha capital. Diez. El Convento de Santa Clara, en Tordesillas. Once. El Convento de San Pascual, en Aranjuez. Doce. El copatronato del Colegio de Doncellas Nobles, en Toledo". Confirmando lo dispuesto en la Ley, se publica el Real Decreto 496/1987, de 18 de marzo, por se aprueba el Reglamento de la Ley 23/1982, de 16 de junio, reguladora del Patrimonio Nacional. Boletín Oficial del Estado de 13 de abril de 1987.

${ }^{61}$ Escritura de modificación de Estatutos de la Fundación Generalísimo Franco-Industrias Artísticas Agrupadas, 22 de mayo de 1984, n. ${ }^{\circ} 1.085$ de la notaría de Antonio Rodríguez Adrados. El nuevo artículo 5. ${ }^{\circ}$ queda redactado de la siguiente forma: "El Patronato de la Fundación corresponde al Consejo de Administración del Patrimonio Nacional".

${ }^{62}$ Escritura de modificación de los Estatutos otorgada por la Fundación Generalísimo Franco-Industrias Artísticas Agrupadas, de 28 de noviembre de 1984, n. ${ }^{\circ} 2.476$ de la notaria de Antonio Rodríguez Adrados. La nueva redacción de los Estatutos figura en el Documento unido, que recoge los acuerdos del Consejo de Administración de Patrimonio Nacional celebrado el 24 de septiembre de 1984.

${ }^{63}$ El Área Textil reunía los talleres de tapices, alfombras, reposteros, bordados y restauración.

Jefe del Área Textil: Cayetano de la Fuente Alonso. Ingresó el 22 de marzo de 1944.

- Taller de tapices:

Jefe de Taller: Fernando Rodríguez Amores. Ingresó el 1 de junio de 1965. Procedente de la Real Fábrica de Tapices.

Tejedores especialistas: Antonia Fernández de la Chica (24 abril 1947). Vicente Casado Blázquez (1 septiembre 1968), procedente de la Real Fábrica de Tapices. 
Antonio Huerta Merino. Petra Salguero Gómez (El apellido Salguero suscita algunas dudas. Parece referirse a la que fue jefe de taller durante el I Periodo, tiempo en el que aparece como Salgado, pero a falta de respaldo documental, simplemente lo dejamos apuntado)

Oficiales de $1^{a}$ A y B: Gregoria Santos Duque ( 28 octubre 1957). Carmen Isidro Vicente, ( 28 octubre 1957). María Pilar López Lorenzo (15 febrero 1958). Manuela Robles Pérez (1 septiembre 1965). Casto Segundo Fernández González (6 febrero 1972). Francisca Soler Gil (2 mayo 1973). Teresa Catalán Sánchez (13 abril 1992). Sagrario Patiño López (3 junio 1992) Ana María Escribano Lozano (s.f.).

Sin clasificación conocida: Juana Díaz López y José Gómez Cuenca.

- Taller de restauración: Concepción Sánchez Sala, también tejedora de tapices ( 1 de marzo 1957). Josefa Sánchez Sala, y de tapices ( 1 de marzo 1963). Cándida Sánchez García, también tejedora de tapices (17 abril 1965). Josefa Garrido Medina, administrativa de restauración (19 mayo 1965); al cierre de la Fundación compró la piscina de lavado y estableció un taller de restauración independiente en Velilla de San Antonio. Felicidad Jiménez Sánchez, y tapices (1 abril 1967). Flora de los Reyes Ronda, también tejedora de tapices de $1^{a}$ ( 1 de junio 1972). José Ignacio García García, y tapices (1 septiembre 1972). José Luis Sánchez Muñoz, también tapices (1 diciembre 1973). Carmen Cervantes Almodóvar, también tapices (1 de diciembre 1973). María Isabel Llanos Cosa, también tejedora de tapices (1 diciembre 1973). Ana Beas Pérez de Tudela Embid, también tapices (1 junio 1974). Teresa Fernández Pérez, también tejedora de tapices (4 noviembre 1974). María Luz San Emeterio Casillas, y tapices (11 junio 1966). Pilar Felguera Medina, y tapices (s.f.). Antonio Sama García (s.f.), al cierre de la Fundación pasó a la Real Fábrica de Tapices.

- Taller de alfombras: Jefe de taller: Benito Díaz Ceballos (21 abril 1966)

María Remedios Rico González (1 febrero 1972). Yolanda Torres Rodríguez (16 febrero 1972). Carmen Fermosel Cobo (16 noviembre 1974). Milagros Moreno Navarro (24 diciembre 1984)

- Taller de sedas: Luisa Manzano Salmerón, jefe de taller, (23 septiembre 1957)

- Taller de tinte:

Luis Mariano López Moreno, técnico (1 septiembre 1972); tras el cierre de la Fundación se integró en la Real Fábrica de Tapices. José María Pérez Jiménez (1 junio 1981). José Gabriel Fernández (s.f.)

- Taller de dibujo de alfombras y tapices:

Antonio Landrobe Jiménez (22 marzo 1944); Benigno Abad de Andrés (2 agosto 1966). Ángel Fernández Surjo (2 junio 1969).

- Jefe de producción: Julio Domínguez García (6 mayo 1991)

- Jefe de formación: Carmen Esteban García (1 diciembre 1986); al cierre de la Fundación pasó con igual puesto a la Real Fábrica de Tapices.

F. $1^{\circ}$ de Mayo. Fondo documental Fundación de Gremios. Sig. 11/16, 11/17, 11/18

${ }^{64}$ Toda la obra tejida de Joaquín Vaquero Turcios en Laura de la Calle Vian, "La obra tejida de los Vaquero y su inserción en la tapicería española del siglo XX", Goya 372 (julio-septiembre 2020): 235-255.

${ }^{65}$ Los tapices que se tejieron en la Fundación sobre modelos de Sempere fueron cuatro, una serie titulada Las cuatro estaciones. Fueron colgados en el Auditorio Nacional de Música de Madrid, donde siguen actualmente. Ver: Laura de la Calle Vian, op. cit., 303-304, 409-491.

${ }^{66}$ En embrión estaban ya en el documento "Esquema para unas propuestas de trabajo" presentado por Arcadio Blasco Pastor en 1978. (Archivo de la Fundación $1^{\circ}$ de Mayo. Fondo documental Fundación de Gremios. Sig. 2/2.) En 1985 la Fundación remite al Ministerio de Industria, Dirección General de la Pequeña y Mediana Industria, el proyecto para el I Taller de Otoño, a celebrar entre el 30 de septiembre al 28 de octubre. "Cursos de adecuación de las artesanías tradicionales a las tendencias, técnicas y diseños actuales". (Archivo de la Fundación $1^{\circ}$ de Mayo. Fondo documental Fundación de Gremios. Sig. 12/289). Los cursos formativos en las diversas áreas continuaron hasta 1992 con el apoyo económico del INEM, pero todos ellos estaban perjudicados por el mismo lastre. Debo referirme a las conclusiones que 
a este respecto llegó el "Proyecto Leonardo", iniciativa conjunta de Italia, España y Francia celebrado en Florencia, Valladolid y París entre 2010 y 2012. La delegación italiana presentó en Florencia un plan basado en la vuelta a la transmisión del oficio según el antiguo modelo de aprendizaje. El mejor escenario para la transmisión de esas destrezas, según la propuesta italiana, es el taller y la relación larga y estrecha entre maestro y aprendiz, añadiendo las enseñanzas complementarias que impidan la corrupción y el anquilosamiento de las formas. Un programa de esa naturaleza fue el que puso en marcha en España la Escuela Mayor de Artesanía y la Fundación en los años cuarenta.

${ }^{67}$ La creación de la Empresa Nacional de Artesanía, luego Artespaña, hay que encuadrarla en los debates sobre la artesanía española que se generaron a raíz del Congreso Nacional, convocado por la Obra Sindical "Artesanía" en 1957. Se debatieron once ponencias sobre los aspectos más relevantes que afectaban al sector y que tenían como objetivo darle un nuevo impulso. Las conclusiones fueron elevadas al Jefe Nacional de Sindicatos para que las tramitara como proyectos de Ley. Esta Obra Sindical tutelaba en la fecha 790 gremios y 295 cooperativas. Ninguna de las propuestas se llega a convertir en Decreto, hasta que toda la documentación del Congreso Nacional se incorpora a los debates del I Plan de Desarrollo (1964-1967), a través del documento "Moción sobre el plan de acción económico-social de la OSA., vinculado al Plan de Desarrollo 1964-1967”. Durante los años transcurridos entre el Congreso de 1957 y 1967, la situación de la Obra Sindical fue precaria y todos sus proyectos (como la apertura de nuevas escuelas artesanas con capacidad para impartir enseñanza a 5.500 nuevos alumnos), estaban paralizados. En 1967 se concede una cantidad insuficiente para cumplir estos objetivos. La situación se prolonga hasta los debates del II Plan de Desarrollo (1968-1971), momento en que se crea una Comisión Nacional de la Artesanía en el seno del Ministerio de Industria, entre cuyos miembros la Obra Sindical era uno más. La Obra Sindical "Artesanía" pierde su papel de motor de la artesanía española. Uno de los primeros cambios introducidos por esta Comisión será la creación de una empresa dedicada a la comercialización de los productos artesanos, que de forma indirecta irá eclipsando a los Mercados de Artesanía. La Comisión ofrece a la iniciativa privada la posibilidad de crear esta empresa, pero no se consigue ningún resultado. En consecuencia el 24 de julio de 1969 se crea la Empresa Nacional de Artesanía con los fines de comercializar los productos de artesanía y asesorar a los artesanos. El Consejo de Administración estuvo presidido por Alfredo Santos Blanco e integrado por vocales que provenían de los Ministerios de Industria, Comercio, Hacienda, Educación, Trabajo, Información y Turismo, Instituto Nacional de Industria, Sección Femenina (Mónica Plaza), y Francisco Lapiedra, director de la Obra Sindical "Artesanía". La promulgación de la Ley Sindical de 17 de febrero de 1971, que permitía la creación de asociaciones profesionales de promoción voluntaria (origen del nuevo sindicalismo independiente), contribuirá a desdibujar poco a poco el papel de la Obra Sindical. Archivo General de la Administración. Secc. Sindicatos. C ${ }^{a} 7842, C^{a} 16.493, C^{a} 16.494$, $\mathrm{C}^{\mathrm{a}}$ 16.519, $\mathrm{C}^{\mathrm{a}}$ 17.100.

${ }^{68}$ La incorporación al Patrimonio Nacional en 1962 dio a la Fundación una seguridad que hizo innecesaria la acumulación de terrenos como garantía económica. Esta razón llevaría a realizar la venta de una enorme cantidad de terrenos, propiedad de la Fundación, a Telefónica para la ampliación de sus servicios y en atención a sus fines sociales. Esta venta a la Compañía Telefónica de España se realizó en tres fases: 15 de julio de 1967, 24 de julio de 1972 y 13 de julio de 1973. Se le venden 830.000 metros cuadrados para "la construcción de edificios e instalaciones y demás elementos destinados a la explotación de sus servicios, y en consecuencia se acogen a la exención tributaria que le ha sido reconocida por las Bases $4^{\mathrm{a}}$ y $7^{\mathrm{a}}$ de su contrato con el Estado". La venta se hace a precio inferior de mercado, incluso cincuenta mil metros cuadrados al precio simbólico total de 15.000 pesetas, en razón de los 
fines antedichos. En 1987 Telefónica no había levantado ninguno de los edificios para cuya construcción había adquirido los terrenos, sino que aporta los solares a una sociedad inmobiliaria para la construcción de viviendas. "Informe venta de terrenos de Fundación de Gremios a la Compañía Telefónica de España”. 28 de diciembre de 1992. Informe firmado por Emilio Jiménez Aparicio el 24 de octubre de 1994.Ministerio de Justicia e Interior. Dirección General del Servicio Jurídico del Estado. Pleitos-Madrid. R.D. 6/94. Archivo Ministerio de Cultura. Fundación de Gremios, Caja 2.

${ }^{69}$ Archivo del Trabajo. Fundación $1^{\circ}$ de Mayo. Fondo documental Fundación de Gremios. Sig. 1/9. El 8 de julio de 1988 se firma la escritura de compraventa; notaria de Agustín Rodríguez García, número de protocolo 1.618.

${ }^{70}$ El traslado a la nueva sede de la calle Labastida 10-12 se efectuó el 16 de Mayo de 1990. Archivo del Trabajo. Fundación $1^{\circ}$ de Mayo. Fondo documental Fundación de Gremios. Sig. 11/189. Certificado final de la dirección de la obra: arquitectos Ignacio de las Casas Gómez y Jaime Lorenzo Saiz-Calleja, de 4 y 5 octubre de 1990. Plantas y alzados Archivo del Ministerio de Cultura. Fundación de Gremios, Caja 2. Expediente de Tasamadrid S.A.

${ }^{71}$ Escritura de modificación de Estatutos otorgada por la Fundación de Gremios-Industrias Artísticas Agrupadas, de 18 de abril de 1989, n. ${ }^{\circ} 759$ de la notaría Antonio Rodríguez Adrados. La nueva redacción se contiene en el Documento unido: certificación de acuerdos del Consejo de Administración del Patrimonio Nacional de 25 de octubre de 1988. El cambio de denominación aparece en su artículo 1": "La Fundación de Gremios-Industrias Artísticas Agrupadas, constituida el 7 de febrero de 1941 y modificada por Escrituras públicas de 4 de diciembre de 1962, 22 de mayo de 1984, se denominará Nueva Fundación de Gremios".

${ }^{72}$ Boletín Oficial del Estado n. ${ }^{\circ} 222$, de 16 de septiembre de 1999.

${ }^{73}$ Acta de 1 de enero de 1946. Nota- Informe de Luis Jordana de Pozas sobre la F.G.F.-I.A.A. Archivo del Ministerio de Cultura. Fundación de Gremios. Libro de actas, pp. 235-246.

${ }^{74}$ Archivo del Trabajo. Fundación $1^{\circ}$ de Mayo. Fondo documental Fundación de Gremios. Sig. $13 / 8$.

${ }^{75}$ En la Memoria presentada por la Fundación relativa al año 1992 se hace una relación aproximada de fondos culturales (el inventario completo estaba por realizarse) en el que se pone de manifiesto el valor de los mismos. Alfombras: 800 bocetos y 1.000 cartones (Cuenca, Alcaraz, Savonnerie, Imperio, Isabelino, Carlos IV, contemporáneos). Telas: 50 puestas en carta y cartonadas de reproducciones de damascos, brocateles, espolines. Tapices: 140 cartones de réplicas históricas y creaciones originales. Reposteros: 200 bocetos y 600 dibujos de motivos heráldicos y decorativos para reposteros y bordados. Muebles: 5.600 plantas de muebles de estilos históricos y contemporáneos. Porcelana: 500 modelos, matrices y moldes, entre los que se encontraba la colección de la Real Fábrica de Alcora. La Biblioteca atesoraba volúmenes especializados en artes decorativas e historia del arte, varios ejemplares antiguos y raros. Además había una colección de 60 pinturas de diversa técnica, autor y época, y una colección de 20 dalmáticas y casullas entre las que destacaba la réplica de la Capa de Daroca. Archivo del Trabajo. Fundación $1^{\circ}$ de Mayo. Fondo documental Fundación de Gremios. Sig. 1/8.

Hay también una relación hecha por el Museo Nacional de Artes Decorativas, adjunta a un escrito firmado por su director de entonces, Alberto Bartolomé Arraiza, enviado a la Dirección General de Bellas Artes el 27 de febrero de 1995, en el que se solicita la adquisición de los fondos para integrarlos en el Museo. Se desprende la importancia del legado cultural que va a dispersarse: la biblioteca tenía libros del siglo XVII y XVIII imposibles de encontrar en el mercado de libro antiguo; el fondo documental, comercial y laboral, de la propia Fundación; la colección de objetos antiguos, adquiridos en los primeros tiempos para la formación de los aprendices; los planos de 
proyectos decorativos completos; prototipos de muebles como los de Feduchi; textiles y porcelanas; herramientas antiguas. Archivo Ministerio de Cultura. Fundación de Gremios. Caja 2.

En enero de 1996 Antonio Martínez Palomino, asesor fiscal, remite al despacho de abogados Héctor y Sempere el inventario definitivo de los bienes de la Fundación, con la descripción del contenido de cada sala. Se describen tanto los objetos artísticos (tapices, bordados, dibujos, porcelanas, etc.) como todo tipo de muebles y accesorios (escaleras, tablones de anuncios, ceniceros, etc.) y el catálogo completo de la biblioteca. Los bocetos originales para tapices de Vaquero Turcios, por ejemplo, que están en paradero desconocido, se valoraron en 150.000 pesetas cada uno. Los bocetos de Farreras, también en paradero desconocido, se valoraron en 65.000 y 75.000 pesetas cada uno (no tenemos constancia siquiera de que llegaran a tejerse). Fernando Durán. Subastas de Arte. Relación de precios de salida a subasta. 9 marzo 1995. Archivo Ministerio de Cultura. Fundación de Gremios, Caja 2.

${ }^{76}$ Libro de actas del Consejo de Administración del Patrimonio Nacional. Archivo General de Palacio. Secc. de Registros. Sig. 9.847.

${ }^{77}$ Archivo Histórico de la Real Fábrica de Tapices. Sig. 83 bis/3.9. y Archivo General de Palacio. Secc. Adm. C ${ }^{\text {a } 2287 . ~ E x p . ~} 6$.

${ }^{78}$ Archivo Histórico de la Real Fábrica de Tapices. Sig. 96/5.2.

${ }^{79}$ Archivo Histórico de la Real Fábrica de Tapices. Sig. 96/4.2, Sig. 96/5.2 y 666/6.8.

${ }^{80}$ Archivo Histórico de la Real Fábrica de Tapices, Sig. 666/6.2.

${ }^{81}$ Archivo Histórico de la Real Fábrica de Tapices. Sig. 664/4, y 666/6.1.

82 Archivo Histórico de la Real Fábrica de Tapices. Sig. 664/4 y 666/6.1.

${ }^{83}$ José Luis B. de Quiñones, "Real Fábrica de Tapices. Futuro incierto", Arriba, suplemento dominical, 4 de mayo, 1975.

${ }^{84}$ Archivo Histórico de la Real Fábrica de Tapices. Sig. 666/6.1.

${ }^{85}$ Archivo Histórico de la Real Fábrica. Libro de registro, n. ${ }^{\circ} 46.1956$

${ }^{86}$ Ibidem, n. ${ }^{\circ} 526$ y 527, 1958; n. ${ }^{\circ} 564,1961 ;$ n. ${ }^{\circ} 697$ y 701, 1964

${ }^{87}$ Ibidem, n. ${ }^{\circ}$ 514, 1958.

${ }^{88}$ Ibidem, n. ${ }^{\circ} 562,1958$.

${ }^{89}$ Ibidem, n. $^{\circ} 865$ y $887,1968$.

${ }^{90}$ Ibidem, n. ${ }^{\circ} 549,1958$.

${ }^{91}$ Archivo del Trabajo, Fundación $1^{\circ}$ de Mayo, Fondo documental Fundación de Gremios, Sig. 8/21 y 11/8 y 13/1; Carta de Stuyck y contestación del Comité de empresa al diario $A B C, 22$ de mayo de 1988; Archivo Ministerio de Cultura, Fundación de Gremios, Caja 2.

${ }^{92}$ A la misma institución americana pertenecían los autores de un importante libro dedicado al mobiliario histórico español, Arthur Byne y Mildred Stapley, Spanish Interiors and Forniture, Nueva York, William Helburn Inc, 1921-1922. Las fotografías y trazas de muchos de los muebles que aparecen en las páginas de este libro, recuerdan a los realizados en el taller de la Fundación durante su primera etapa, así como a los dibujos de su catálogo de muebles destinado al mercado norteamericano.

${ }^{93}$ Acta de la sesión del Consejo de Administración de 19 de diciembre de 1942. Archivo del Ministerio de Cultura. Fundación de Gremios. Libro de actas, pp. 116-117.

${ }^{94}$ Archivo General de la Administración, Fondo Sindicatos, C ${ }^{a} 16.491$.

95 "Hacia una renovación del arte del tapiz", Revista de las Artes y los Oficios, n. . 2, (julio 1944): 17-20.

${ }^{96}$ Un estudio detallado de este plan de estudios en: Laura de la Calle, op. cit., 233-248, 478483.

97 "El renacimiento del tapiz español", Revista de las Artes y los Oficios, n. ${ }^{\circ} 3$, (agosto 1944): 8.

${ }^{98} \mathrm{El}$ modelo fue el cuadro del mismo título, también conocido como Bosque con figuras y caballos, fechado en 1945. 
99 Colección del Palacio de Navarra. 1952.

${ }^{100}$ Archivo General de la Administración, Fondo Sindicatos, C ${ }^{a}$ 17.100.

${ }^{101}$ Ley 194/1963, de 28 de diciembre.

Fecha de recepción: 1 de enero de 2022

Fecha de revisión: 12 de enero de 2022

Fecha de aceptación: 24 de enero de 2022 